Literature Reviews

\title{
Political Rhetoric or Policy Shift: A Contextual Analysis of the Pivot to Asia
}

\author{
${ }^{1}$ Lucas Bittick and ${ }^{2}$ Timothy Sands \\ ${ }^{1}$ University College, International Affairs, Washington University, St. Louis, MO 63130 USA \\ ${ }^{2}$ Department of Mechanical Engineering (CVN), Columbia University, New York, NY 10027, USA
}

\author{
Article history \\ Received: 03-10-2018 \\ Revised: 29-05-2019 \\ Accepted: 16-08-2019 \\ Corresponding Author: \\ Timothy Sands \\ Department of Mechanical \\ Engineering (CVN), Columbia \\ University, New York, NY \\ 10027, USA \\ Email: timsands@caa.columbia.edu
}

\begin{abstract}
Society lays witness to the rise and fall of civilizations throughout history. Following a proud past, in recent times China has suffered low-years whose fall was precipitated by experiments in poor governance exacerbated by relatively better-governed states leveraging Chinese weakness to their own benefit. In the century, China has abandoned failed governance schemes and is again on the rise in a world that simultaneously welcomes its rise, yet remains cautious to defend against territorial aggression too often associated with rising societies; in hopes of avoiding horrific wars seen in the previous century. Societies across the world are left contemplating the contemporary politics of the USA and this manuscript evaluates whether the so-called pivot to Asia is a legitimate shift in contemporary politics or merely political rhetoric.
\end{abstract}

Keywords: State-Formation, Borders, Rise of the Modern Nation-State, Xenophobia, Effects of Border Discourse, Nationalism

\section{Introduction}

This paper will explore the Obama administration's pivot to Asia aspect of foreign policy. The concept of an Asian Pivot is globally significant, since it represents U.S. acknowledgement that the global balance of power has changed and that U.S. instruments of national power (i.e., diplomatic, economic and military resources) need realignment in recognition of Asia's importance. Primarily, this shift has been driven by the advancement of China as both an economic power and as a military power in the Asia-Pacific. Recent literature, i.e. Sands (2007-2018) buttressed by the 2014-2018 works of Nakatani, Heidlauf, Cooper, Smeresky, Baker, and Lobo clearly highlights the new military emphasis areas, but what of economic and diplomatic? This literature is The literature clearly indicates the American response has driven military counter-strategies coupled with technological development; meanwhile the Chinese perspective seems to indicate military and technology developments to reinforce continued economic prosperity growth. This disparity obfuscates the need to long contemplate the political shift from the side of value and economic condition. As the U.S. is both the world's single largest economy and military power, any U.S. strategic realignment deserves attention and evaluation because of its potential effects on the global balance of power. In a speech to the Australian Parliament in 2011, President Barack Obama, stated:

As President, I have, therefore, made a
deliberate and strategic decision --as a
Pacific nation, the United States will play a
larger and long-term role in shaping this
region and its future, by upholding core
principles and in close partnership with our
allies and friends

Specifically, about six years after the Obama administration's announcing the pivot as a strategic shift, this paper will assess evidence to determine the extent to which an Asian pivot represents substantive policy change rather than political rhetoric. In short, this paper will examine the following questions: Did a foreign policy pivot occur (or is it in the process of occurring); and, if so, will the pivot endure as a national grand strategy?

To answer these questions, this paper will first briefly explain the first use and development of the pivot to Asia designation as a strategic foreign policy concept. Then, it will summarize historical and emerging geopolitical issues, placing particular emphasis on the roles of regional heavyweights Japan and China, in order to establish the diplomatic, military and economic contexts within which 
the U.S. has responded. It will then attempt to distinguish measurable activities within the economic, diplomatic and military elements of national power and identify major concrete actions taken by the Obama administration falling under an Asian pivot/rebalance classification. Finally, it will explain where the pivot to Asia body of action/policy is situated in the realm of international relations theory and evaluate whether the Obama administration has actually undertaken a rebalance to Asia by assessing the durability and potential impacts of identified measurable actions.

\section{Results}

\section{The Pivot to Asia Designation: Development and} Occurrence

In 2011, the Obama administration began articulating a new foreign policy initiative of shifting military and diplomatic focus to Asia. In communicating renewed focus on Asia, then Secretary of State Clinton (2014) made use of the word "pivot" multiple times in a Foreign Policy article entitled "America's Pacific Century." Its first sentence reads: "As the war in Iraq winds down and America begins to withdraw its forces from Afghanistan, the United States stands at a pivot point." Its last sentence asserts: "This kind of pivot is not easy, but we have paved the way for it over the past two-and-a-half years and we are committed to seeing it through as among the most important diplomatic efforts of our time." In asserting that the "pivot is not easy," Clinton most certainly recognized that shifting military priorities and refocusing instruments of national power in a coordinated fashion requires much thought, coordinated effort and resources from policy makers, diplomats and political leaders.

Proof is scarce the Obama administration directly intended the overall policy adjustment to take on the exact label of "pivot to Asia." In introducing the strategic shift in his speech to the Australian Parliament, President Obama used terminology such as "new focus" and "play a larger role", However, Clinton's pointed use of the verb "pivot" in her Foreign Policy piece combined with established use of the term by foreign policy experts has evidently provided sufficient credibility for pivot to Asia to attain widespread use in the news media as common phrase describing Obama administration foreign policy focused on Asia. According to Clinton, "... [j] ournalists latched on to it [the "pivot to Asia" phrase] as an evocative description of the administration's renewed emphasis on Asia, although many in our own government preferred the more anodyne rebalance to Asia."

The English-speaking news media indeed favored the "pivot" designation-by an order of magnitude. Beginning in 2010, written news mentions of the term "pivot" within five words of "Asia" or "Asian" occurred half as much as the term "rebalance" within five words of "strategic," with all occurring at a relatively low frequency of less than 50 times. However, by 2014, media mentions peaked, with "pivot" occurring 2,238 times, versus 265 occurrences of "rebalance." Clearly, following Clinton's first use of the term "pivot" as a foreign policy undertaking, the conversation and descriptions inherent in written media coverage exhibit marked increase in use of the term in association with Asia.

Following the election of President Barack Obama in 2008 and particularly as a reaction to the 2008 financial crisis, Chinese sentiment expected a more restrained U.S. foreign policy, as "Beijing looked for his election to herald an era of U.S. geopolitical retreat and weakness that would cement China's arrival on the world stage."

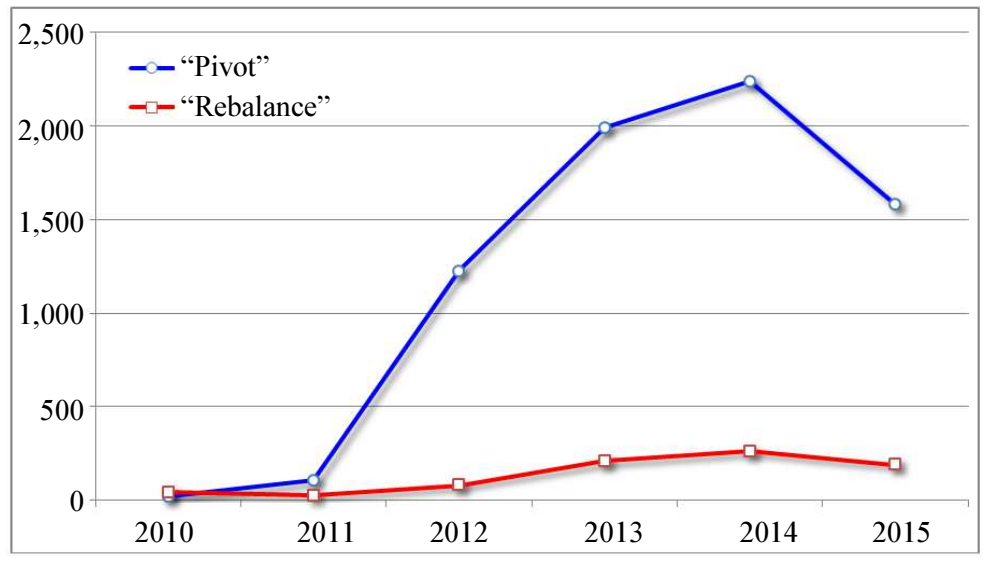

Fig. 1: Occurrence of "pivot" vs. "rebalance" in written news media since 2010 [Data source: LexisNexis Academic] 
Most certainly, the reaction from China to the pivot policy was generally not positive, with responses that "excite a lot of the old Cold War thinking ... what they [China] mostly fear is that somehow they will be contained, that there is some kind of big plan to encircle them. This brings back memories of when China was very isolated during the Cold War." The ensuing Chinese disappointment following a realization that Obama's foreign policy posture would not conform to initial expectations plausibly served to enhance Chinese frustrations and increase feelings of insecurity. However, according to former Secretary of State Henry Kissinger in 2014, the Chinese concern that a U.S pivot policy is foundational to a grander U.S. strategy to check Chinese ascendency is "all the more remarkable because it has not involved any significant military deployments at the time of this writing." As further analysis will demonstrate, Kissinger's assessments (1994-2019) continue to hold true. Nonetheless, increased militarization increases chances of confrontation and the development of a Pacific-focused Asian pivot policy is most certainly a response to China's increasing political, economic and military capability to compete with the U.S. as a regional rival in the Pacific.

\section{The United States: Over a Century as a Pacific Power}

Well before the United States was regarded as a global superpower, it had expanded into the Eastern Hemisphere, with economic exchange as "a catalyst leading to Pacific relations." Although economic exchange with China is popularly regarded as a preeminent and modern political issue, such has been the case for much of the last century. As a matter of historical record, the United States undertook a dramatic pivot to Asia at the turn of the 19th century, when "President William McKinley's (18961901) administration was the first significantly to engage U.S. power across the globe." Envisioning Manifest Destiny, in 1811 John Quincy Adams saw the U.S. as "a nation, coextensive with the North American continent, destined by God and nature to be the most populous and most powerful people ever combined under one social compact." As Americans moved and settled westward, "contiguous territorial expansion" was complete by 1853; Alaska and Hawaii were annexed in 1867 and 1868 respectively. In 1887 , the U.S. developed a naval base and accompanying coaling station at Hawaii's Pearl Harbor, which provided vital re-fueling and logistics support for U.S. fleets in the middle of the Pacific Ocean, thus extending naval power projection capability across the Pacific by obviating the need to return to the West Coast for re-coaling.

A seemingly European engagement-the SpanishAmerican War in 1898-resulted in the U.S. acquiring the Spanish colonial possessions of Puerto Rico and Cuba in the Western hemisphere and both Guam and the Philippines in the Eastern Hemisphere, at a time when the American public was amenable to expansion. By colonizing the
Philippines and establishing a naval base at Subic Bay, the United States culminated its rise as a Pacific power." U.S. presence in the Philippines, according to Combs (2012), "naturally prompted greater American interest in Asia. The dream of a great China market, one of the primary reasons the McKinley administration decided to annex the Philippines, now beckoned even more invitingly."

With access to the Chinese market a strategic priority, the rights of access to foreign markets as well as the stability of China were important concerns for American decision makers. "[President] McKinley was straightforward about his ambitions. Markets had to be obtained to secure U.S. power, economy and the "American way of life." With U.S. policy placing a priority on trade security, two events revealed the vulnerability of China and therefore, threatened to erode U.S. commercial interests. First was the unanticipated 1895 Japanese victory in the Sino-Japanese war. The Japanese victory over the Chinese Qing dynasty in Korea caused "the last of its prestige crumble" and "... [t]riggered a final rush of 'concessions' by the European powers." Second, the U.S. observed that "Germany, Russia, France and Great Britain had seized harbors suitable for naval bases along the coast of China" along with extracting long-term leases "and economic concessions in neighboring areas" from the Chinese government. The perceived vulnerability of China to competitive foreign influence from European powers through "extortion of leaseholds and concessions" in China "prompted the United States to issue the Open Door Notes in 1899 and 1900." The Open Door Notes established the "Open Door Policy," essentially an agreement to liberalize trade as well as to prevent China from being partitioned by outside powers. The Open Door Notes "insist[ed] that the European empires respect the territorial and administrative integrity of China and to permit equal commercial access to its market rather than dividing that country into specific spheres of influence and zones of economic privilege." According to Ryan (2000), "the Open Door notes had a profound impact on subsequent U.S. diplomacy. The ideas advocating the notion of equal access of all powers, first specifically to the trade of China and then more widely applied, formed the basis of US policy on trade in to the future." Of significant note, however, U.S. diplomats neither consulted nor coordinated with the Chinese Government on the issuance of the Open Door notes, despite the profound impact on Chinese domestic concerns.

\section{Boxer Rebellion and a Weakened China}

Simultaneous to the U.S.-issued Open Door Notes, "[a] grassroots anti-foreign insurrection in northern China, known as the Boxers, came to receive support from some Chinese officials and by 1899 and 1900 it was carrying out widespread attacks foreign missionaries and Chinese Christians." 
The United States acted with military force in conjunction with other Western powers to quell the uprising with a joint force of about 20,000 troops and, as with the Open Door Notes, did so without consulting the Chinese Government. Then "[Secretary of State John] Hay and [President William] McKinley sent 2,500 American troops from the Philippine War to join the forces of the other European powers in an expedition that set off from the China coast to rescue the besieged foreigners in Beijing." Once again, the U.S. had projected its military power across the Pacific and it had leveraged its recently attained position in the Philippines to do so. Following the violence and loss of life resulting from the Boxer Rebellion, the foreign powers imposed the Boxer Protocol upon China in 1901 , levying "an indemnity of $\$ 333$ million to pay for damages and loss of life in China"-well over $\$ 8$ billion in present-day monetary value. Although the U.S. did not participate in the Opium Wars of the mid-nineteenth century, joining in combined military operations with the great European powers did little to enhance Chinese esteem of the United States. According to Ryan (2000), ignoring modern-day civil affairs constructs such as "[c]onsent, legitimacy, constituency and representation [was] not considered problematic".

By 1912, the weakened Chinese government faced revolution and the ruling Qing dynasty collapsed 70 years after its initial conflicts with Western powers. Faced with domestic turmoil, China remained vulnerable to outside invasion, which would come most dramatically from Japan in 1937.Japan's continued imperialist expansionism during World War II would goad a response from the U.S. following Tokyo's decision to attack Hawaii in 1941.

There is thus over a century's precedent of United States political and military involvement in the AsiaPacific region, with U.S. armed forces commitments reaching an apex in World War II and economic exchange still continuing to grow.

In short, the U.S. has “... worked hard for more than a century to gain hegemony in the Western Hemisphere. After achieving regional dominance, it has gone to great lengths to prevent other great powers from controlling either Asia or Europe." With little dispute, the U.S. controlled the global political landscape of the twentieth century, becoming accustomed to the privileges associated with economic and military might, while plainly announcing hegemony as a national strategic goal in political speech, official national security strategy documents and in concrete actions.

\section{The Significance of Japan}

As a practical matter, Japan would be significant in any discussion of Asian affairs simply based on its standing as the world's third largest economy after the U.S. and China. Moreover, Japan plays a central role in evaluating U.S. actions in the Asian region, particularly vis-à-vis China, for three fundamental reasons.

First, Japan is the first Asian nation to engage globally since the emergence of the Westphalian order and its historical experience can inform other nations seeking to participate on the global stage. Japan's leadership chose direct engagement versus isolationism when confronted with external, so-called "gunboat diplomacy" military threats from the U.S., signing the first formal agreement between Japan and a foreign power (the Treaty of Amity and Friendship, also known as the Treaty of Kanagawa, signed in 1854). Observing that a single warship in Commodore Matthew C. Perry's naval battle group "had more firepower than almost all of Japan's shore batteries combined," Japan used a potential crisis as impetus for profound internal social and institutional changes paving the way for rapid modernization. Emerging from over 200 years of self-imposed national seclusion, Japan undertook the daunting task of modernizing all at once-facing "an onslaught of problems European countries had encountered and overcome over a period of 400 years." According to Auslin (2011) "it is no stretch to say that Perry's visit ignited a technology boom in Japan." Such rapid modernization arguably created a prototype for Chinese aspirations nearly a century later. The manner in which the Chinese economy has expanded "since 1978 has much in common with Japan's initial stirrings during the Meiji period and then the formidable industrial expansion in 1955-73."

Second, Japan's global participation in the early 20th century evolved into a period of imperial expansionism that resulted in confrontation with China leading up to and including in World War I and later with the U.S. in World War II. By 1895, Japan became a regional hegemon-it altered the balance of power in Asia for the next century and prevailed over China in the Sino-Japanese War, concessions of which included Korean independence from Chinese tributary status and the cession of Formosa (known today as Taiwan). Ten years later in 1905, Japan "stunned the world" by defeating the Russian Empire in war, representing the "first defeat of a Western country by an Asian country in the modern period." Along with Western powers, Japan played a significant role occupying a weakened China as a conquering force in 1937 and during WWII, thereby featuring strongly in China's modern sense of vulnerability and ongoing sensitivity to any perception of exogenous coercion. Previous Japanese conflict with China, in particular, continues to have ramifications on modern-day Chinese sentiment. Importantly, according to Wang (2012):

A deep historical sense of victimization by outside
powers, a long-held suspicion about foreign
conspiracies against China and the powerful
government education and propaganda


campaigns on historical humiliation have worked together to construct a special Chinese 'culture of insecurity.' Thus, this culture of insecurity has become the frame by which the Chinese interpret present-day events and influences their reactions and demands to rectify perceived humiliation

Third, despite the bloodshed in World War II as the U.S. defeated Japanese hegemonic designs in Asia, Japan and the United States maintain an exceptional postwar security alliance that is fundamental to the current international order. After the U.S., "... Japan remains the second largest contributor ... to the United Nations system, the World Bank, International Monetary Fund and ADB [Asian Development Bank]," along with hosting the "largest number of U.S. troops $(50,000)$ of any U.S. ally abroad." The relationship between the U.S and Japan has evolved from trading partners coerced through gunboat diplomacy, wartime enemies and trusted military and commercial alliance over the 160-plus years since Commodore Matthew Parry sailed into Tokyo Bay in 1853. According to Packard (2010), the current alliance created under the US-Japan Security Treaty is exceptional in international affairs, as "no alliance between major powers has lasted so long since the origin of the modern nation-state beginning with the Peace of Westphalia in 1648. Not a single word of the treaty has been changed for over a half century, even though since 1970 either side could have called for its abrogation by giving one year's advance notice of its intent to do so."

Therefore, the U.S. as the world's largest economy and Japan, as the world's third largest, can exert considerable clout as a political alliance. The circuitous route Japan has taken through modernization, militarization and globalization, along with accounting for regional historic grievances against past Japanese imperialism, can offer insights into potential U.S. posture as its political leadership evaluates courses of action in an "Asian pivot" response to China's growing role in Asian regional affairs and its ever increasing participation in the global political economy.

\section{Taiwan and the Korean Peninsula}

Although the governing institutions and cultures present on Taiwan and the Korean Peninsula have long and rich histories, this section will focus on selected geopolitical events and relevant background for the purposes of evaluating the Asian pivot policy. Lodged between two great powers, the divided Korean peninsula stands as a tangible geo-political remnant of Cold War era balance-of-power conflict (Fig. 2). The state of war on the Korean Peninsula, combined with the diplomatic ambiguity and strategic importance surrounding Taiwan, are prime factors in evaluating potential outcomes of a pivot to Asia strategy.

\section{Taiwan: Fulcrum of a Balancing Act}

Taiwan (officially, the Republic of China) stands both as an emblem of Mainland China's contemporary clout and as a geopolitical reminder of its current frustrations. As spoils of the 1895 Sino-Japanese war, the Treaty of Shimonoseki awarded Japan with the Island of Taiwan. After WWII, Taiwan again came under Chinese control. However, in the turbulent years preceding the establishment of the People's Republic of China under Mao Zedong in 1949, 2 million Chinese Nationalists fled to Taiwan and established a government under the 1947 constitution [originally] drawn up for all of China," establishing martial law on Taiwan under the leadership of Chiang Kai-Shek. As a result, Taiwan harbored "Nationalist China" in exile and Mainland China became "Communist China," allied with the Soviet Union.

Taiwan's geographic position in the South China Sea is strategically significant (Fig. 2). During the Cold War, at the beginning of the Korean War in 1950, Gen. Douglas MacArthur warned that Taiwan was "'an unsinkable aircraft carrier' and "would 'threaten completely sea traffic from the south and interdict all sea lanes in the western Pacific." The communist bloc's use of military force on the Korean Peninsula during the Cold War embedded protection of Taiwan into U.S. security policy and cemented U.S.-China distrust. Hence, the path to the U.S. officially acknowledging the People's Republic of China was well encumbered until the Sino-American rapprochement of the late early 1970 s.

As a prelude to establishing official diplomatic ties with the People's Republic of China, the Chinese Communist Party and the Nixon administration agreed on the Shanghai Communiqué during Nixon's historic visit to China in 1972, wherein the current "One China" policy, maintaining that Taiwan and Mainland China are inseparable, was acknowledged by the U.S. Therefore, U.S. acknowledgement of the "One China" policy can be construed as foundational to the ongoing modern diplomatic relationship between the U.S. and China.

Taiwan's turn toward democracy has added another element of risk to Mainland China's "One China" policy and by extension, Chinese Communist Party legitimacy. In the late 1970s, the Taiwan Nationalist government began democratization, removed martial law in 1987 and "held its first direct presidential election in 1996".

The Carter administration continued down the Nixon administration's path to full normalization of relations with Mainland China, but coincident to democratic reforms on Taiwan, rebuffed China's proposed compromise of a "one country, two systems" approach and instead pursued the Taiwan Relations Act in 1979, pledging to "arm and defend Taiwan in the event of an 
attack by China." Thus, the current status of Taiwan in U.S. policy is one of strategic ambiguity and a continued source of irritation for China.

Using its growing, centrally controlled economic influence, China has leveraged economic coercion in relation to a wide range of issues and it has been particularly successful in compelling other nations to conform to its notions of the "One China" policy, demanding "... that any country desiring to enter into diplomatic relations with it must cut off ties with Taiwan."

Notably, China has not forsworn armed conflict to accomplish governing Taiwan under the "One China" policy. According to official Chinese statements, Taiwan independence is regarded as "the greatest threat to China's national integrity" and "the biggest threat to China's sovereignty," with Chinese law requiring the "use of 'non-peaceful' means as may be needed to prevent independence."

China intentionally escalated threats of violence during the 1995 Taiwan Straits Crisis, which erupted after the U.S. broke 16 years of precedent and granted Taiwan leader Lee Teng-Hui a visa to speak at his alma mater, Cornell University. "Beijing reacted quickly and furiously," recalling its ambassador in the days after Lee's visit, rejecting the newly appointed U.S. ambassador to China and staging a series of three large military exercises simulating an invasion of Taiwan. In response, in March 1996, the U.S. deployed two aircraft carriers to the region as a deterrent. "After tempers cooled in the wake of ... the crisis, however, U.S. efforts to get along with Beijing-coming as they did on the heels of Chinese assessments of continuing U.S. strength...-led to a fairly comfortable period in Sino-American relations".

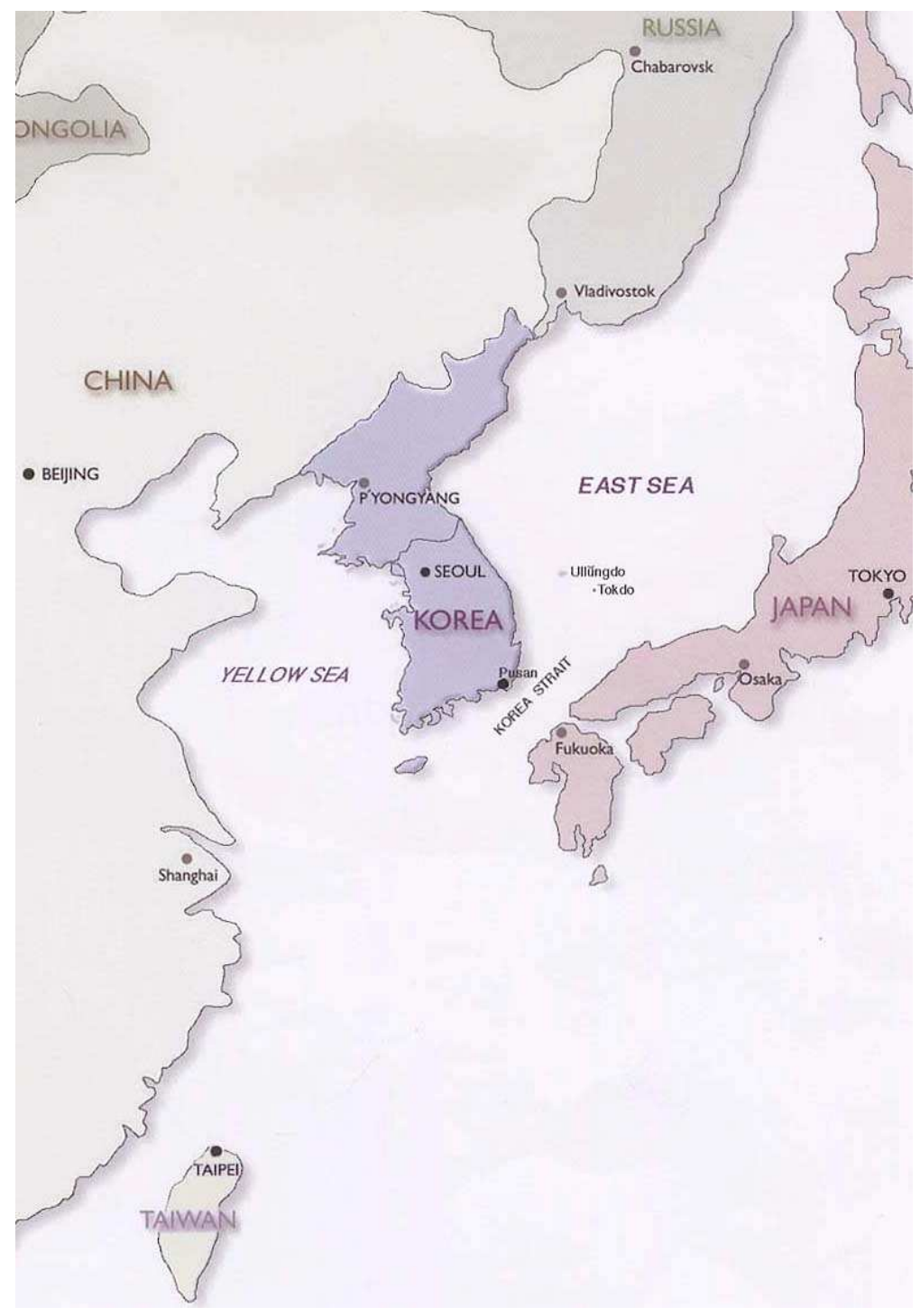

Fig. 2: Geography of Taiwan and the Korean Peninsula relative to China and Japan [Source: University of Texas Libraries] 
Hence, a tenuous equilibrium regarding Taiwan persists, as the Chinese adherence to the "One China" policy appears even less likely to change than U.S. pledges to arm and defend the island. Should China elect to take Taiwan by force, the U.S. would be compelled to determine if a potentially distant war would be in its national interest. It was forced to confront the same questions in the Cold War-era Asian wars of containment; continued threats of war on the Korean Peninsula along with memories of upended domestic politics in the wake war in Korea and shortly thereafter, Vietnam, have left lasting impressions on U.S. policy makers contemplating war in Asia.

\section{Two Koreas: Still at War}

As a small peninsular kingdom bordering Imperial China, Korea was long a loyal Chinese tributary state; when expansionist Japan took Korea in a decisive 1894 naval engagement during the Sino-Japanese War, China was shaken and humiliated. Korea's economy expanded under Japanese colonial rule, particularly in the 1920s, as a strengthened and prosperous Japan invested capital into the colony, resulting in industrialization and transportation infrastructure. "1945, Korea had one of the most extensive rail networks in Asia."

As a result of World War II, the Korean Peninsula was liberated from Japanese occupation and “... a democratic-based government (Republic of Korea, ROK) was set up in the southern half of the Korean Peninsula while a communist-style government was installed in the north (Democratic People's Republic of Korea, DPRK)." "Neither the Soviets nor the Americans has planned for the occupation of Korea," but by 1949 the divided Korean Peninsula became the first in a series of battlegrounds where the U.S exercised a containment approach to Soviet-backed communist expansion.

To reduce risk of uncontrolled regional war and gain public support for action in Korea, President Truman dispatched naval forces to the Taiwan Straits, calling on the "Chinese Government on Formosa to cease all air and sea operations against the mainland;" ... "[the Seventh Fleet will see that this is done." However, unknown to Truman, Mao Zedong had planned to attack Taiwan and was in the process of assembling military forces; he thus regarded the U.S. move as entering the Chinese civil war and interfering in Chinese internal affairs.

On 25 June 1950, communist North Korea began a surprise attack on the militarily inferior South Korea; the U.S. gained a United Nations mandate and intervened in the conflict with 80,000 marines, defeating the North Korean advance and pushing northward across the North-South border, the 38 th parallel, into North Korean territory. Lacking any formal diplomatic relationship with the U.S. and already aggravated by perceived U.S. intrusion in its affairs with Taiwan, China sent advance notice through its Indian ambassador that it would not tolerate U.S. forces on its border in Korea. Mao made good on the threat and interceded with Chinese armed forces and while taking on enormous losses, pushed the U.S.-led invasion back to the 38th parallel. Fighting ceased in 1953 and "[a]fter nearly 100,000 American casualties (and an estimated 200,000 Chinese deaths), the conflict came to an end with both sides occupying the same territory they had held when the war began." Thus began a mid-20th century great power struggle in Asia, ushered in with the Korean War, which "... destroyed any prospects for Sino-American rapprochement during the 1950s and pushed the Soviets and Chinese closer together."

"The United States was responsible for the very survival of the ROK [South Korea], which would have lost the war to the north in 1950 without American intervention." Along with infrastructural and institutional capacity left behind after Japanese colonial occupation, "[t]he United States established the environment within which [South] Koreans effected first an economic 'miracle' followed by a breakthrough to sustainable democracy," ascending to the "trillion-dollar club of world economies" in 2004. Additionally, because of the continued standoff against North Korea, the U.S. maintains a bi-lateral security agreement and about 40,000 troops in South Korea, with tensions exacerbated by North Korean nuclear capability (Appendix 4).

The collapse of the Soviet Union created an existential crisis for North Korea; no longer under the Soviet nuclear umbrella and observing the folding of Europe's Eastern bloc regimes (like East Germany), North Korea pursued its own independent nuclear deterrent in the early 1990s. Its conspicuous tests of tests of nuclear devices in 2006, 2009, 2013 and 2016 have caused much international concern about stability in Asia and puts China in an uncomfortable position as North Korea's last remaining communist ally. Fearful of a U.S. presence on its border, a collapse of the North Korean regime would almost certainly guarantee a democratic unification of the Korean peninsula along with the security umbrella already provided to South Korea by the U.S. However, according to Westad (2012), "Chinese leaders simply believe that North Korea and its nuclear weapons are much more controllable if there is a close relationship with China than if there is not." Concurrently, this does not earn China friends in South Korea. "Whatever happens next in North Korea, Chinese leaders will have a real task on their hands in convincing the South Korean public the China stands on their side in their wish to unify their country".

Taiwan and more generally, South Korea, represent tangible threats to Chinese Communist Party legitimacy. Taiwan's turn toward a democratic government 
empirically displays the concept of "Chinese democracy" is not a contradiction in terms. Additionally, South Korean democratization and runaway economic success stand as a contrast to the enfeebled communist North Korea. The military impasse on the Korean Peninsula and the persistent strategically ambiguous relationship between the U.S., Taiwan and China sets the stage for Chinese pushback stemming from geo-political security concerns, that is, encirclement by foreign powers and resentment at foreign restraints on expressions of Chinese territorial sovereignty, that is, fulfilling nationalistic aims of a "One China" policy by repatriating and controlling Taiwan.

\section{China and Ambitions of Hegemony}

That every East Asian country can trace fundamental cultural and political influences to China as a regional hegemon would not be an understatement-the written historical record of the last few thousand years in East Asia reveals consistent political, linguistic, technological and cultural ties to China. With one of the world's oldest recorded histories, China could accurately be characterized as the Rome of East Asia. However, by the 1700 s, China became a closed country by imperial decree and remained isolated until confronted by European colonial powers. The year 1839 was a modern turning point: when the U.S. was still a developing nation, Imperial England attacked China in the first of the Opium Wars to force the country open to trade. According to economist Sachs (2005), the "collision between Europe and an inward-looking China was tumultuous and violent." By the turn of the 18 th century, the U.S., along with the European Great Powers, made regular incursions into China in pursuit of balance of power politics in the Asia. As a direct result of weakened Chinese imperial power and increased internal divisions, China was invaded by Japan in 1937, serving a "crushing blow to the domestic political order of China." After the 1945 Allied defeat of Japan in World War II, China was left "devastated and divided," with Nationalist and Communist factions vying for control of the country. "[O]pen civil war with ... [Mao Zedong's Communist] People's Liberation Army (PLA) broke out; as a result, [Nationalist] Chiang Kai Shek fled to Taiwan in 1949 and the modern-day People's Republic of China was founded in October of that same year. At the height of the Cold War, the U.S. reached out to China, seeking to maintain Cold War stability while exiting its war in Vietnam and triangulating with Russia; ultimately, "[c]ooperation with China would alter the balance of power and give the Soviet Union and incentive to come to its own accommodation with the United States."

In 1976, succeeding Mao after his death, Deng Xiaoping instituted economic reforms throughout the 1980s, attracting foreign investment into China. Deng (2014) originated limited capitalist initiatives, while maintaining a position of "bide our time and build up our capabilities." As a result, "[o]ver $\$ 7$ billion of foreign direct investment flowed in to China between 1979 and 1987." Despite China's adherence to a one-party communist government and overall opposition to democratic reforms (expressed with violence by the Chinese state against reformist protesters in the Tiananmen Square massacre of 1989), China's increasing economic liberalization made deepening political relations more palatable to U.S. leadership.

Whereas the U.S. has consistently gained power and global prestige as it has developed, the Chinese narrative of the last century is one of losing power and losing face. China's so-called "century of humiliation," beginning with the First Opium War in 1839 and concluding with the Sino-Japanese War in 1937, is also "referred to as China's 'treaty century' because so many foreign powers forcibly required China to sign a series of devastating agreements following military defeats." Post World War II, with the U.S. a de facto architect and defender of the international liberal order, China had to contend with U.S involvement in wars of containment at its periphery (on the Korean Peninsula and in Vietnam), along with a Taiwan integrated into U.S. defense strategy. According to Ford (2015) "[t]he imperative of making China stronger-and, ultimately, returning it to the place of global status and power that it is said to deserve and that it enjoyed in ages past-runs like a central nerve through Chinese politics and strategy."

China is now more open to the world than ever, but with relatively recent occupation by European powers and Japan over the last hundred years, combined with ongoing fears of encirclement, Chinese leaders are extremely wary of foreign interferences. Such guardedness is visible in the form of military growth, financed precisely through China's openness to global trade.

\section{China's Military Power}

Modern China's rapid economic expansion has allowed it the financial means to swiftly grow its military. China has maintained a large standing army since World War II, but its more recent pursuit of expanding PLA naval capability is an affirmative indication of Beijing's desire to extend military power beyond its shores.

China's defense growth is certainly a strategic concern for the United States; it is the duty of military planners in both China and the U.S. to prepare for worstcase scenarios. In comparison to the U.S., "China does not publish a 'National Security Strategy' document that spells out its overall strategic interests and goals," which serves to introduce speculation and increase regional fears. Since the end of the Cold War, strengthening traditional alliances with Japan, South Korea and 
Australia has been a U.S. priority in the Pacific region in response to the growth of Chinese military power.

With Chinese on the trajectory to create a blue-water navy, future U.S. challenges include stability of its Pacific alliances, with Taiwan, in particular. China has made it clear that Taiwan is a rogue province subject to the "One China" policy and must eventually be repatriated and repeatedly engages in political tough talk directed toward its former wartime enemy and modern U.S. ally, Japan. In the last decade, the modern military relationship between the U.S. and China has been marked by three key events: The Hainan Spy Plane Incident, the deployment of Chinese naval forces to the Gulf of Aden and the USNS Impeccable Incident. Although each event signaled an evolution in the military relationship between China and the U.S., military power and projection capability must first be considered in global context.

The U.S. has consistently led the world in military spending. In 2015, U.S. defense expenditures totaled $\$ 596$ billion dollars and China's spending ranked second, totaling \$215 billion dollars (36 percent of world total expenditures for the U.S. and 13 percent of world totals for China). If one considers U.S.-allied European nations a single entity, then Europe ranks second in global defense spending totaling approximately \$328 billion. Therefore, using 2015 defense expenditure data, U.S. military spending is nearly double that of Europe and roughly three times greater than China's (Appendix 2). In such context, it is clear that the U.S. defense budget (and its corresponding defense capability) far exceeds that of any other nation.

Therefore, it is reasonable to consider that the context of U.S. hegemony, along with a recent history of invasion, provides a strong incentive for China to strengthen its defenses. "The U.S. is identified by Chinese analysts as the most important external force impacting China's maritime security interests, which not only include Taiwan, the East China Sea and South China Sea, but also China's sea lane security." Near China's east coast "front yard," the United States has sought and accomplished hegemonic naval influence in the Pacific since World War II and is well accustomed to such hegemony going relatively unchallenged throughout the Cold War era to the present. Consider Gen. Douglas MacArthur's remarks in his 1951 farewell address to Congress:

Our strategic frontier then shifted to embrace the entire Pacific Ocean, which became a vast moat to protect us as long as we held it. Indeed, it acts as a protective shield for all of the Americas and all free lands of the Pacific Ocean area. We control it to the shores of Asia by a chain of islands extending in an arc from the Aleutians to the Marianas held by us and our free allies. From this island chain we can dominate with sea and air power every Asiatic port from Vladivostok to Singapore-with sea and air power every port, as I said, from Vladivostok to Singapore-and prevent any hostile movement into the Pacific.

Such a far-reaching hegemonic capacity could not forever go unchallenged and China has indeed moved to use its military capability to more vigorously defend its interests and challenge U.S. hegemonic presence in the Pacific. Not long after the election of President George (2016), an unarmed U.S. EP-3 surveillance aircraft made an emergency landing at a Chinese naval air base on Hainan island, following a collision with a Chinese interceptor fighter jet, which resulted in the death of the Chinese pilot. Now commonly referred to as the Hainan Spy Plane Incident, the situation served to increase tensions between China, which maintains the U.S. airplane violated its airspace and the U.S., which demanded the return of the jet (containing sensitive intelligence equipment) and its crew, insisting that the aircraft had remained over international waters. After 11 days of rhetoric and tension, the disassembled aircraft and 24 crewmembers were returned to the U.S. following an official apology to the Chinese government.

The focus of the United States' defense establishment shifted dramatically following the September 11 terrorist attacks on the World Trade Center and the Pentagon. Any realist-leaning interest groups wishing for a formal policy of military containment directed toward China would have seen their hopes dashed as U.S. national defense policy quickly turned toward invading Iraq and Afghanistan, along with combating non-state terrorist organizations.

Despite the Hainan Spy Plane incident, China did little to assert itself militarily throughout the presidency of George (2016), continuing a posture of "bide our time and build our capabilities." Given strategic shifts in economic and military resources toward the so-called "Global War on Terrorism" following the invasion of Iraq, the U.S. likely had little chance of pursuing a containment policy toward China even had there been political will to do so. Meanwhile, as "the United States pursued its wars in Afghanistan and Iraq, China's GDP almost tripled".

Former Secretary of State Henry Kissinger argued that a containment policy would not be tenable, writing: "Paradoxically, the best strategy for achieving antihegemonic objectives is to maintain close relations with all the major countries of Asia, including China." In 2005, then Deputy Secretary of State Robert Zoellick (2007) articulated the "responsible stakeholder" concept for China, comprising, in his words:

... given China's success, its size, its rising influence, it has an interest in working with other major countries to sustain and strengthen the international systems that keep the world more secure, enable it to be more prosperous and open opportunities for our peoples. 
In the spirit of the "responsible stakeholder" policy, the U.S. engaged with multinational forces to include China in an offensive initiative off the coast of Somalia. A little under a decade ago, Chinese naval forces participated in their first multilateral operation off the coast of Somalia. "The Chinese People's Liberation Army (PLA) made its debut in the world arena on Dec. 26, 2008. On this day, the PLA dispatched two navy battleships and a supply vessel to protect Chinese merchant vessels from Somali pirate attacks in the Gulf of Aden."

What is now known as The Impeccable Incident underscored China's willingness to assert claims over its national maritime boundaries in challenge to U.S. military operations, beginning a consistent display of increasing aggression designed to communicate territorial boundary claims in the South China Sea. Over the course of two days in March 2009, Chinese ships took unprecedented action to aggressively interfere with the USNS Impeccable, a Navy surveillance ship on mission in the South China Sea. According to Pentagon statements, a Chinese frigate approached Impeccable "and proceeded to cross its bow at a range of approximately 100 yards." A short time later, interference occurred again "by a Chinese Y-12 aircraft conducting 11 fly-bys of Impeccable at an altitude of 600 feet and a range of 100 to 300 feet." The next day, a Chinese intelligence collection ship challenged Impeccable over bridge-to-bridge radio, stating her actions violated international law and ordered and the ship to "leave the area or "suffer the consequences." The incident would prove to be a harbinger of events to come.

The USNS Impeccable was conducting surveillance and reconnaissance in the same broad area along China's east coast where the 2001 U.S. Spy Plane incident occurred. Since 2009, Chinese assertiveness in the South China Sea has escalated and evolved into more forceful territorial claims.

\section{Challenges to Post WWII Balance of Power in Asia}

U.S. security commitments require naval access and global trade with Asia relies on maritime trade routes through the East China and South China Seas; therefore, control over rights of maritime passage is Asia is a mark of national power. China has made sweeping territorial claims in the South China Sea, running up against territorial claims of multiple nations in Asia and conflicting with U.S. demands for freedom of navigation. Concurrently, a gap in multilateral capacity to resolve grievances and disputes creates a "might makes right" security environment.

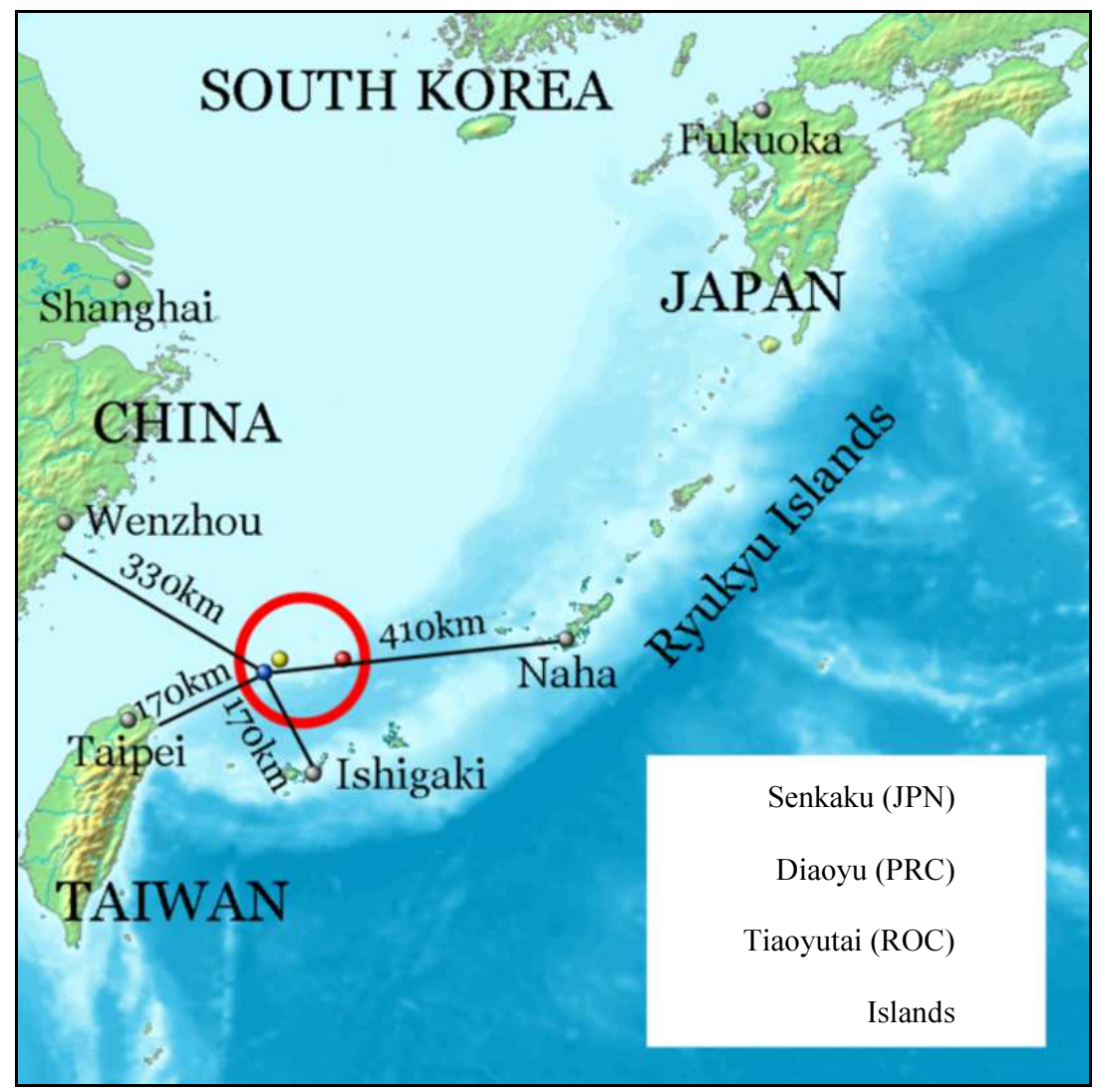

Fig. 3: Location of the Senkaku/Diaoyou/Tiaoyutai Islands [Source: Drifte, 1] 


\section{East China Sea: The Senkaku Islands}

The Senkaku islands are hard geographic symbols of Chinese and Japanese geo-political competition. China and Japan have in recent years experienced escalations in their mutually disputed claims over the uninhabited Senkaku Islands (known as the Diaoyou Islands in Chinese), located in the East China Sea. Although the East China Sea is 360 nautical miles wide, both China and Japan claim 200 nautical miles as their Exclusive Economic Zones (EEZs), as is standard under international law.

Chinese and Japanese EEZ claims overlap the Senkaku islands, which Japan has claimed since 1895 based on the principle of terra nullius (vacant territory)-a claim disputed by China, which cites Ming Dynasty-era (1368-1644) documentation that it first discovered the islands. To further complicate matters, Taiwan also claims the island chain (which it calls Tiaoyutai), asserting the landmasses "were one of its provinces for centuries until 1895, following the end of the SinoJapanese war." China supports Taiwan's claim, employing the logic that "since Taiwan is part of China, the islands too are part of China." Following U.S. occupation of Japanese territory in the years after World War II, the U.S. gave control over the Senkakus back as a part of the return of Okinawa Prefecture administration to Japan in 1971. Coincident to the U.S. return of Okinawa administration and the included Senkaku Islands, “... the Bangkok-based Economic Commission for Asia and the Far East (ECAFE) surveyed the waters around the [Senkaku Islands] and suggested potentially rich oil deposits beneath the seabed;" shortly after ECAFE released its report in 1971, Taiwan made its first territorial claims to the islands and China followed in the months thereafter.

Before 2012, China had entered the waters around the Senkaku Islands only four times; however, beginning in September 2012, China dramatically altered its approach to the ongoing dispute, initiating maritime patrols around the islands and thus increasing the frequency of its incursions into Japanese territorial waters surrounding the Senkakus. Such incursions caused Japan to dispatch naval and air forces in response, increasing the risk of a potentially destabilizing confrontation wherein each side would find it increasingly difficult to back down. Notably, following a meeting with Japanese Defense Minister Satoshi Morimoto in 2012, then U.S. Defense Secretary Leon Panetta confirmed that the Senkaku Islands would fall under that U.S.-Japan mutual defense treaty, stating, "the United States would fulfill its obligations under that treaty." Therefore, because of U.S. defense agreements, the Senkaku Islands are one of the flashpoints that could pull the U.S. into a shooting war in Asia if reactions to overlapping territorial and EEZ claims are not carefully managed. The Senkaku
Islands are thus the geographic confluence of Chinese historic grievances against Japan and by extension, the United States.

Adding another layer of sovereignty claim to the East China Sea region, China officially declared an Air Defense Identification Zone (ADIZ) in the East China Sea at the end of 2013, overlapping the Senkaku Islands and consequently, transecting Japan's ADIZ along with Korean and Taiwanese ADIZs. The Chinese ADIZ announcement utilized coercive language that "emergency defensive measures" would be used for aircraft failing to identify themselves. Days later, the U.S. flew two nuclear-capable B-52 long-range bombers over the Senkakus, with the Pentagon confirming “... a demonstration of long-established international rights to freedom of navigation and transit through international airspace." Since then, the U.S. has maintained its stance on freedom of navigation and has continued to send flights over the islands.

Since October of 2013, China has reduced the frequency of naval patrols to now follow a predictable and stable pattern of the "3-3-2" model: "three patrols a month, with three ships and for two hours." The previous period of escalation beginning in 2012, along with continued patrols into waters claimed by Japan, is clearly designed to send a message to Japan that China is willing to more forcefully contest traditional Japanese sovereignty claims over the Senkakus and related portions of the East China Sea. Concurrently, the escalation and continued incursions also send an unmistakable message to the U.S.: given its role as a protective ally of Japan and hegemonic naval power in the Asia-Pacific, China is now willing to challenge the U.S.-led status quo in the region and assert its national power, which is occurring even more forcefully in the South China Sea.

\section{South China Sea: China's Expansive Claims}

Consistent with its assertiveness in the East China Sea, China has made even greater claims to sovereignty over the South China Sea. China has invoked its historical relationship to the South China Sea in asserting an expansive EEZ within a boundary it calls "the ninedash line," encompassing nearly all of the South China Sea's waters. Such a large sovereignty claim clashes with the claims made by six other states: "China, Taiwan, Vietnam, the Philippines, Malaysia and Brunei-five of which (all but Brunei) occupy some of the [South China Sea's] islands with military or paramilitary forces (Fig. 4)."

As in the East China Sea, China has employed naval power to confront rival claimants' territorial claims. The territorial dispute escalated in April 2012 around the Scarborough Shoal, when Philippine authorities attempted to "... stop Chinese fishermen from taking 
what were said to be poached sharks, clams and rare corals from the area, two Chinese marine surveillance boats intervened," initiating a standoff where Chinese naval vessels essentially blockaded Philippine fishermen from the islands. The Philippines brought its Scarborough Shoals territorial dispute with China to international arbitration at The Hague, which invalidated China's territorial claims as inconsistent with international laws of the sea; however, the decision has been roundly rejected by China.

Setting the stage for conflict with the U.S., "China's claims of sovereignty over the waters, along with more aggressive posture in defending territorial claims, have "effectively sought to preclude and deny certain U.S. activities in and military-related access to, the EEZ in the South China Sea." The U.S. has not assumed an official policy position relative to the territorial disputes, but it champions right of free naval passage, conducting regular freedom of navigation naval patrols and exercises in the South China Sea.

Furthermore, since 2012, China has conducted largescale land reclamation, adding a total of 3,200 acres to seven of its eight claimed outposts in the Spratly Islands. To date, China has begun erecting military installations on the reclaimed land in the Spratlys, which China's Foreign Ministry claims are for defensive use, stating, "As for necessary military installations, they are mainly for defense and self-protection and are legitimate and lawful' ... 'If someone makes a show of force at your front door, would you not ready your slingshot?"

China's continued claims and "island building" activities through unprecedented land reclamation and militarization indicate it will continue to assert sovereignty over the majority of South China Sea waters based on the historical "nine-dash line" boundary claim. The pivot to Asia by necessity must account for the South China Sea when defending U.S. strategic interests, as a closed South China Sea would destabilize maritime trade and would impede U.S. naval access in military support of regional allies.

Although the Hague ruling has created an important opening for the U.S. to stand behind a rules-based system, developing a rules-based approach to managing conflicting claims in the South China Sea will be impossible without China's consent, which appears unlikely at this juncture. By not offering constructive alternatives or openings to compromise, China in fact increases incentives for weaker Pacific nations to ally with the U.S. for protection, thus intensifying U.S. resolve to maintain naval access. Because of the thicket of conflicting claims, the U.S. has very limited options to take sides on territorial issues without upsetting any one or more of the six territorial claimants. With its interests coalescing around unimpeded access, the U.S. has continued freedom of navigation patrols throughout the past year. However, increased militarization of disputed land features in the Spratly Islands grouping by China indicate the struggle for sovereignty over the South China Sea is perhaps in its opening act.

The "might makes right" approach employed by China against relatively weaker states in the South China Sea region will inevitably lead to war if interested participants decline to deliberately commit to peaceful resolution. Both the East China Sea and Couth China Sea situations thus illuminate a gap in available multiparty dispute resolution mechanisms.

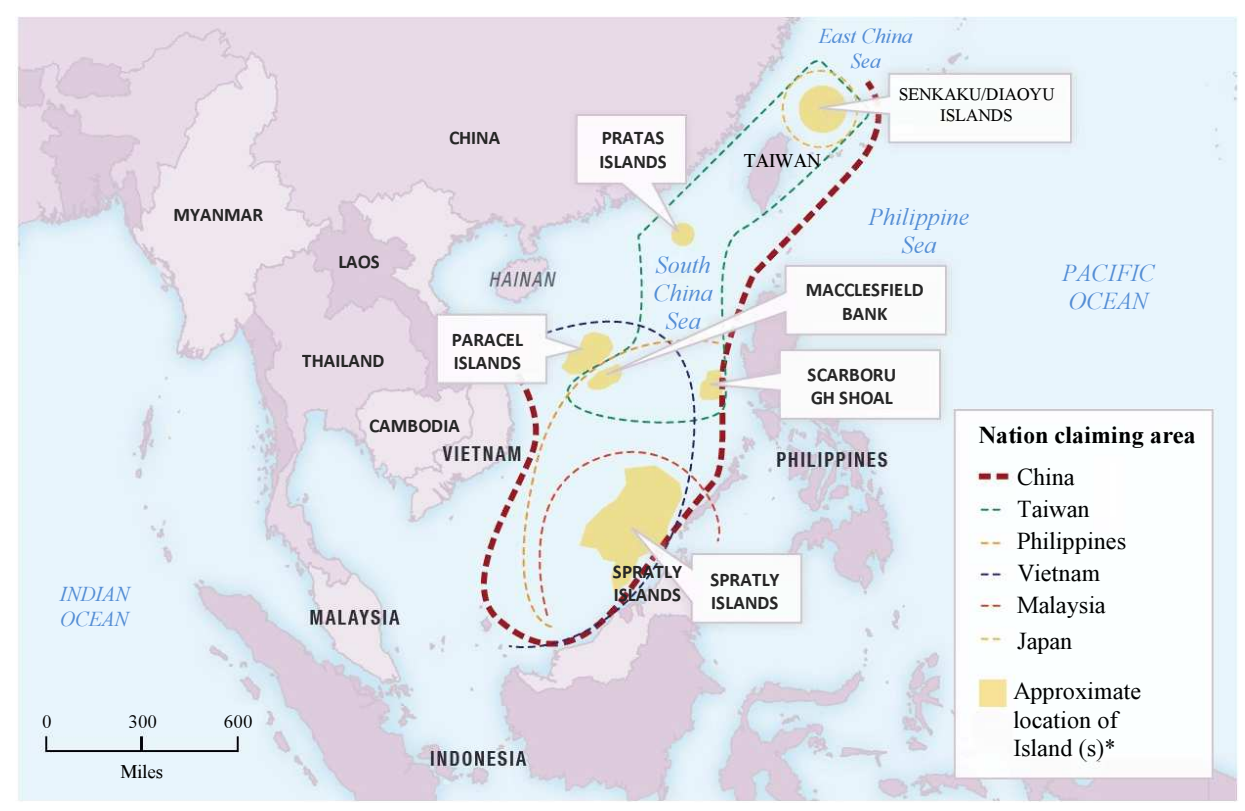

Fig. 4: South China Sea territorial claims [Source: Katie Park, NPR News] 


\section{Missing Multilateralism in Asia}

Even a cursory foreign policy assessment reveals that the Asia Pacific is lacking in multilateral international security organizations. After World War II, at the opening of the Cold War, ideological struggles between the great powers during the restoration of the international order coalesced geographically and the U.S. "viewed Europe as the central battleground in the nascent Cold War." As a result, the North Atlantic Treaty Organization (NATO) was created to defend Western Europe against the expansionist Soviet Union. According to Patrick (2009), "[t]he extreme asymmetry in power between the United States and the Asia-Pacific countries, which possessed only modest resources to devote to the anti-Communist struggle, encouraged Washington to take a more hierarchical approach in Asia."

With communism no longer an ideological threat to U.S. hegemony, the vestiges of the Cold War remain: bilateral defense agreements prevail and a multilateral security arrangement in the Asia-Pacific is noticeably absent. According to Cha (2010), U.S. war planners wished to avoid entanglement with grievances between various nations in the Asian region, hence:

... the United States created a series of tight, deep
bilateral alliances with Taiwan, South Korea and
Japan through which it could exercise maximum
control and prevent unilateral aggression.
Furthermore, it did not seek to make these
bilateral alliances multilateral, because it wanted
to amplify U.S. control and minimize any
collusion among its partners

Consequently, the U.S., in hegemonic competition with China, is now under pressure to adjudicate disputes between its allies and a more assertive China willing to challenge rules and norms. The ageing "hub and spoke" system of alliances with the U.S. at the center has lost some utility following the conclusion of the Cold War and dynamic economic development in the Asia-Pacific. With U.S.-allied Japan and South Korea less likely to initiate unilateral hegemonic military action against their neighbors, the U.S. has the option to take the lead in designing a multilateral security alliance in the Asia Pacific, beginning in volatile East Asia. By nature, the most powerful nations in a multilateral alliance cede their potential unilateral decision-making authority to less powerful states; however, the previously feared Cold War scenario of communist nations aligning against U.S. interests is today extremely unlikely. The rising complexity of Asia-Pacific economic interdependence combined with increased militarization in the East China and South China Seas further illuminate the gap in multilateral partnership capacity in East Asia and it is likely the U.S. will increasingly find it difficult to manage regional affairs on its own should China increase activities contesting maritime access. Thus, according to the Department of Defense, "As tensions in Asia rise and the security situation becomes more complex, there is a growing need for credible, capable regional institutions that provide forums for frank discussion on difficult issues, facilitate practical multilateral security cooperation and build trust."

Just as the contemporary European Union had its origins in a multilateral tariff agreement, the vigorous trade environment of Asia presents opportunities for multilateral economic agreements that could potentially set the stage for broader diplomatic and security cooperation between U.S. allies to transition from the current "hub and spoke" system of bilateral alliances to a multilateral approach with the U.S. as a participant. Although the U.S. would cede immediate influence within a multilateral framework, the long-term gains would result in increased stability in the Asia-Pacific. As this writing will further explore, the wide-ranging free trade agreement known as the Trans-Pacific Partnership has potential to establish an enduring multilateral approach to Asia-Pacific affairs.

\section{Assessing the Pivot}

This section will examine selected indicators across economic, diplomatic and military areas of U.S. national power to determine whether a pivot to Asia has occurred or is in progress. With an ever-expanding portion of world trade stemming from Asia, economic exchange and associated movements of capital will continue to exert substantial influence on balance of power calculations.

\section{Increasing Economic Interdependence}

The complexity of global economic interdependence is often underestimated in popular political conversation, as it encompasses more than simple nation-to-nation trade or the outsourcing of labor. Each domestic economy comprising the global economy has varying resources at its disposal, along with fluctuating domestic pressures in the realms of human capital, social entitlements obligations, currency values, national debt and trade imbalances. The economic linkages of the United States and nations in the Asia-Pacific no less complicated, taking place in an integrated global economic environment where price fluctuations in system-wide commodities markets (for items such as copper and petroleum), can have serious economic consequences that cascade through supply chains. Given the depth of trade, this is particularly true for the U.S.China trade relationship; therefore, discussing trade in the context of hegemonic competition necessitates acknowledging the complex global economic system in which both countries function. 


\section{U.S.-China Economic Ties}

Despite the double-digit growth of recent years and visible wealth accumulation within certain regions, China is still classified as a developing economy by the World Bank based on its per capita Gross Domestic Product (GDP). In 2015 its per capita income of $\$ 14,450$ per person was more than double that of Vietnam (\$6,035 per capita), but among longstanding U.S. allies, the benefits of protracted bilateral trade agreements with the U.S. becomes evident (Fig. 5). China's per capita GDP stands at 26 percent of that in the United States (\$56,116 per capita), 39 percent of that in Japan (\$37,322 per capita) and 42 percent of that in South Korea $(\$ 34,549$ per capita). Additionally, if one evaluates Taiwan an individual economic entity, its per capita GDP of $\$ 46,800$ is over three times that of China's. China's greatest growth has occurred in the last 40 years, as per capita GDP has grown from $\$ 978$ in 1978 to $\$ 14,450$ in 2015 .

As globalization has steadily increased over the past forty years, "China has benefited both from good fundamentals-low labor and materials costs, 'outward orientation' in the form of SEZs [Special Economic Zones], large market size-and from a determined government effort to acquire domestic capabilities and build a modern industry." China's endowment of comparatively inexpensive labor has allowed it to grow as a manufacturer, receiving significant amounts of Foreign Direct Investment (FDI), with domestic business and monetary policy oriented toward an export-led economy. Exploiting its comparatively cheaper labor costs, China prolifically exports to industrialized nations with higher labor premiums, with the U.S. ranking at the top. Presently, China continues to be the largest supplier of U.S. imports, accounting for nearly 16 percent of total foreign trade with the U.S. valued at $\$ 381$ billion.

With so many goods flowing out of China requiring so much foreign currency to flow in, the level of monetary exchange has reached the point at which global markets are affected by the scale of capital movement. China has the world's largest foreign exchange reserves, which peaked at $\$ 4$ trillion in 2014. As a general rule, investors of capital seek the safest investments with the greatest returns. After financial crises in Asia and Russia in the late 1990s, global capital sought secure and liquid investment instruments. Because of its exports, China gains a considerable surplus of capital that seeks low risk and a large amount of China's capital surplus goes into U.S. Treasuries. Despite the U.S. financial crisis beginning in 2008 and the resulting so-called Great Recession, foreign investors' desire for U.S. treasuries has not declined. As of September 2016, China continues to be one of the single largest holders of U.S. Treasuries with Japan not far behind, with $\$ 1.16$ billion and \$1.14 billion invested respectively. This paradigm creates an enmeshed symbiotic relationship between China, Japan and the United States, one of economic interdependence, that no one nation can manipulate on a whim to its own advantage. Despite political tough talk during the 2016 U.S. presidential election to cut off trade with China or drastically raise tariffs to move manufacturing jobs back to the U.S., the reality of financial interdependence is much more complicated.

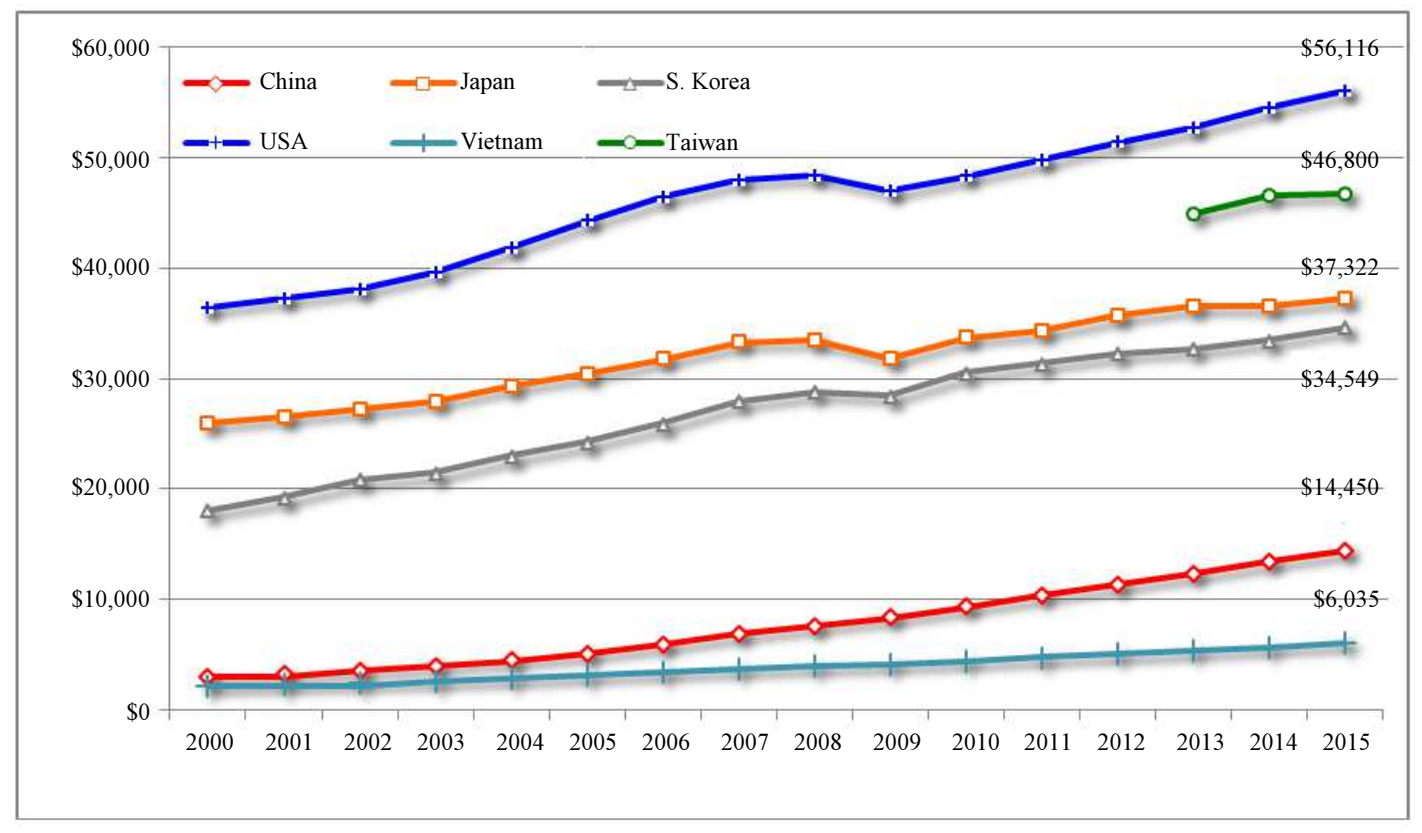

Fig. 5: Per capita GDP (PPP) since 2000, selected economies [Data (except Taiwan): World Bank; Data, Taiwan: Central Intelligence Agency, "Taiwan"] 
In response to the financial shocks of 2008 and ensuing Great Recession, the U.S. has held interest rates at historic lows in order to maintain liquidity in the financial system. During the financial crisis, "Chinese interest rates were higher than U.S. interest rates and the RMB [Chinese national currency] was rising against the dollar;" therefore, currency traders found the Chinese RMB more lucrative than U.S. dollars, resulting in "far more foreign exchange ... coming into China than was going out. The [Chinese] government had to constantly buy up foreign exchange to keep it from sloshing around in the market" Such pressures have resulted in a large currency surplus for China, which has incentive to invest the surplus in the safest of investments: U.S. Treasuries, which are the debt instruments used to finance the U.S. government deficit. In short, dollars going into China have been reinvested back into the U.S., financing cheap credit. Thus, in the interconnected world of global finance, U.S. Treasury investors such as China have allowed the United States to continue financing its budget at historically low rates without having to make drastic cuts to expensive programs, for example: defense spending.

Hence, the U.S. and China are at an economic impasse of sorts: The U.S. has relied on Chinese investment to support cheap credit and China needs the U.S. to buy its exports in order to finance continued growth. Such an arrangement makes it difficult for either China or U.S. to use economics and trade as a means for coercion, thus the Obama administration's pursuit of multilateral economic diversification: The Trans-Pacific Partnership.

\section{The Trans-Pacific Partnership}

In its current form, the Trans-Pacific Partnership (TPP) Free Trade Agreement (FTA) framework is a groundbreaking compact by nearly every measure. For example, the U.S. trades about $\$ 1.9$ billion in goods to the 12 TPP countries every day. The 12 signatories of the TPP have a combined population of "about 800 million-almost double that of the European Union's single market," and the group of nations is "... already responsible for $40 \%$ of world trade".

The seeds for the current TPP framework were planted 10 years ago, when only four Pacific countries (Brunei, Chile, Singapore and New Zealand) inked the first free trade agreement linking Latin America, Asia and the Pacific. Later, the U.S. joined negotiations; and "[o]ver time, TPP drew in four \$1 trillion-plus economies (Australia, Canada, Mexico and Japan), as well as three smaller emerging ones (Vietnam, Malaysia and Peru)."

Such an agreement does not take shape without determined effort by all signatories involved and the Obama administration has clearly devoted considerable work to negotiate TPP "rules of the road"-its completion stands as the confluence of eight years of both diplomatic and trade efforts. The U.S. Trade
Representative describes TPP as "the cornerstone of the Obama Administration's economic policy in the Asia Pacific," and critical to establishing "rules of the road" for trans-Pacific trade. Given ever-increasing trade volume and the absence of strong multilateral agreements and institutions to govern trade in the AsiaPacific, it is evident China has designs on returning to its traditionally central role as a rule maker in Asia, championing "... establishment of alternative financial institutions to the World Bank and the Asian Development Bank in the form of the Asian Infrastructure Investment Bank (AIIB) that can further promote economic integration of the region." Therefore, in short, if the U.S. does not take the lead in shaping a future system of rules for Asian trade, then China will most certainly do so, perhaps using methods of economic coercion to bend the rules in its favor.

Ironically, the biggest obstacle to full ratification of TPP by Congress is domestic politics. President-elect Trump ran against TPP and has stated he will withdraw from the agreement on his first day in office. Campaigning on a mixture of "America first" populism espousing suspicion against free trade agreements, but coupled with a desire to accrue U.S. economic advantage (particularly vis-à-vis China), it remains to be seen in 2017 if a new Trump administration will be swayed by the potential economic power and influence TPP could provide the U.S. in the Asia-Pacific as a part of the Asian pivot.

\section{Military Indicators}

The U.S. Maintains a Significant overseas military presence in East Asia, with nearly 50 thousand troops stationed in Japan and nearly 30 thousand stationed in Korea (Appendix 4). Given the overall quantity, unpredictable variability of equipment and personnel, along with often-classified status of military operations, a simple count of military operations is not sufficient to evaluate military posture relative to a "pivot" strategy. Furthermore, most military operations tend to be short term in nature (for example, freedom of navigation operations in the South China Sea) and although an increase in operations tempo could predict broader force realignment, such a conclusion could only be realized in retrospect. Therefore, to evaluate military realignment in the intermediate term (3-5 years) and the long term, the most effective aggregate measurements are military end strength statistics.

Military end strength is formally defined as "the maximum number of personnel each of the military services is authorized [by Congress] to have on the last day of the fiscal year (September 30)." In practice, the Department of Defense reports end strength on a monthly basis by geographic distribution as the number of active duty and civilian personnel on station during a given reporting period. In short, although Congress 
authorizes a maximum yearly number of personnel for each branch of service, the Department of Defense decides how to align those forces in the global theater. The 2012 end strength measure represents the earliest reporting period that the Department of Defense could react to an Asian pivot strategic realignment. Therefore, beginning with 2012 DoD End Strength measurements, this paper charts total end strength and also extracted geographic end strength distribution for each branch of service (Army, Navy, Marine Corps and Air Force) in Europe and Asia and Pacific. Setting the context for analysis, DoD total military end strength was 1,393, 948 in 2012. Total aggregate end strength fell by 88,656 personnel from 2012 levels to 1, 305, 292 in 2015 (Fig. 6). A large portion of this reduction can be explained by continued drawdown from Iraq and Afghanistan military engagements in the Middle East.

Looking specifically at European and Asian areas of operations, one can observe that all areas had a concurrent decline in workforces until 2014, when end strength in Asia increased by 28, 431 personnel (Fig. 7).

Analysis of total civilian personnel end strength shows a similar trend, spiking in 2013 and then falling to 733, 720 personnel by 2015 (Fig. 8).

Examining geographic distribution of Department of Defense civilians, just as with the military personnel distribution, civilian end strength measures increase in the Asia Pacific region concurrent to a reduction in Europe and simultaneous to an aggregate reduction in overall end strength (Fig. 9).

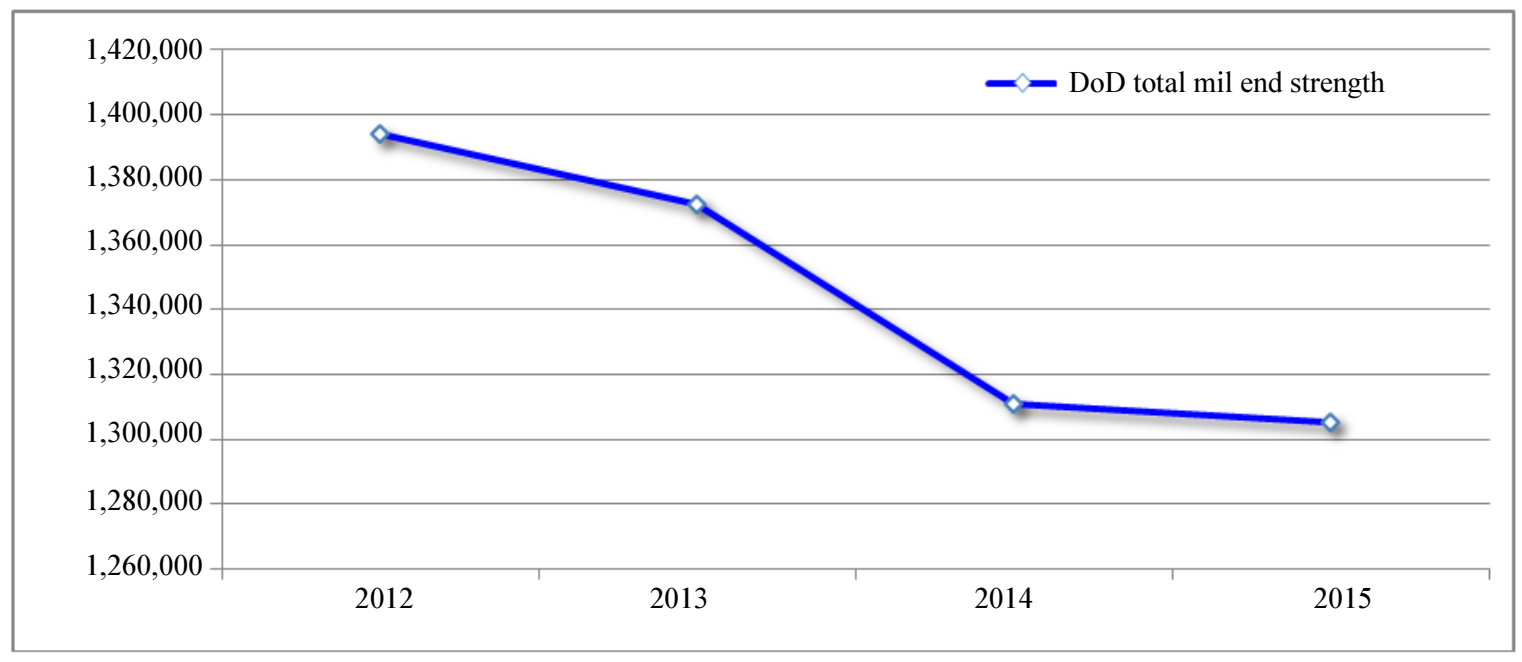

Fig. 6: Total U.S. military end strength from 2012-2015 [Data source: Defense manpower data center]

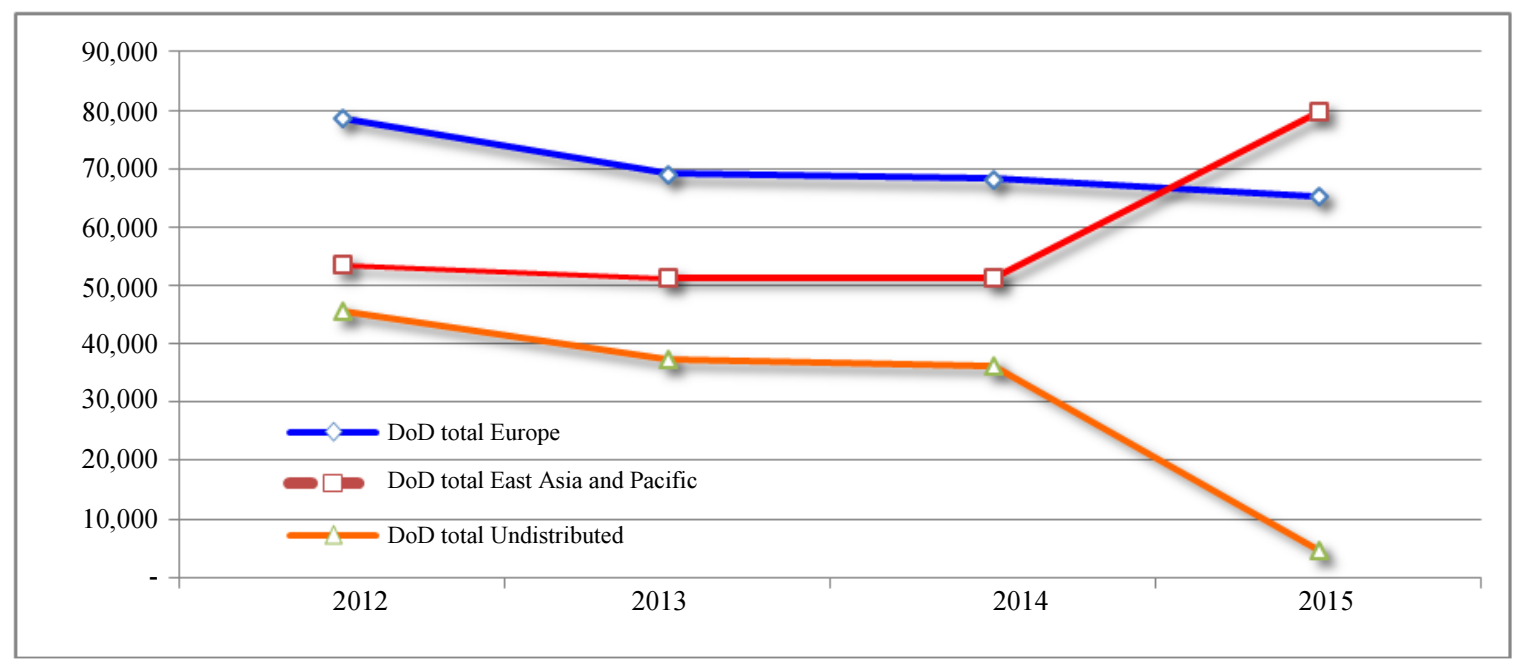

Fig. 7: Total U.S. military end strength in Europe and Asia from 2012-2015 [Data source: Defense manpower data center] 


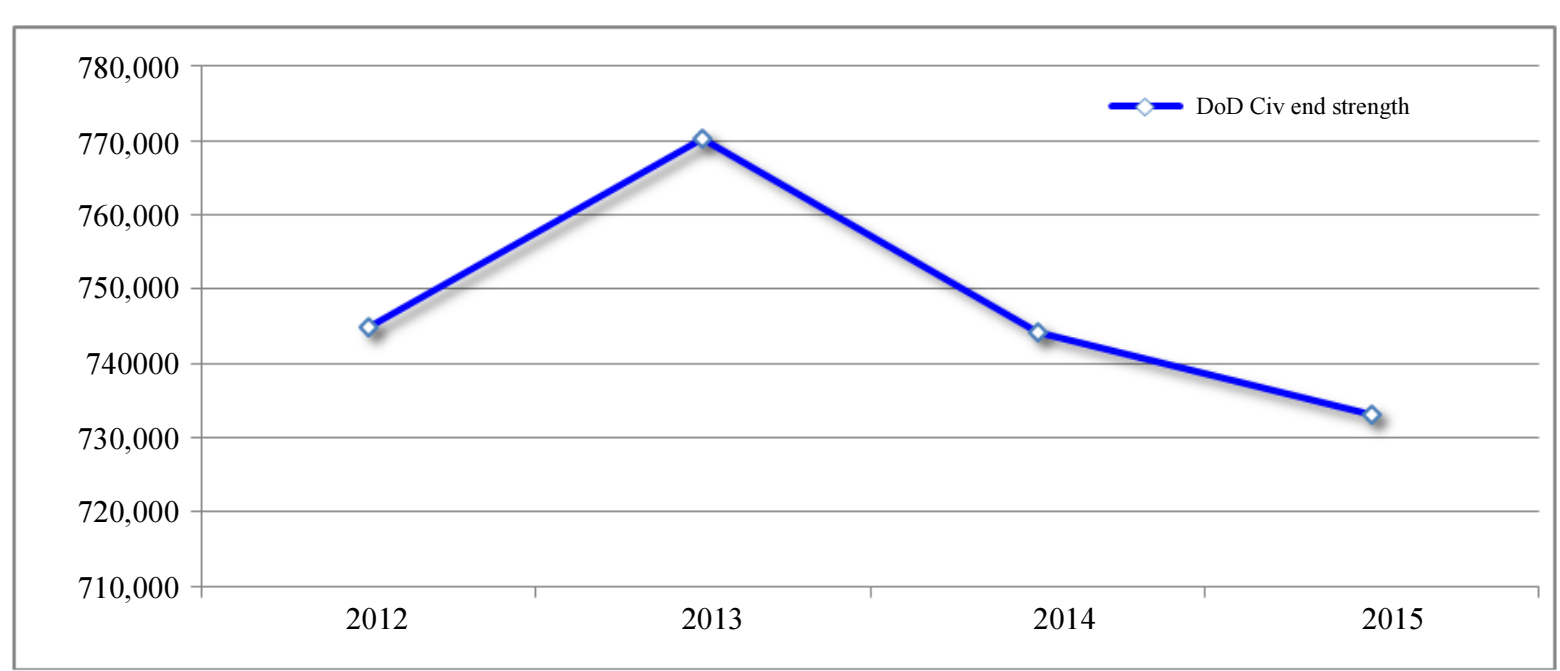

Fig. 8: Total DoD civilian end strength from 2012-2015 [Data Source: Defense Manpower Data Center]

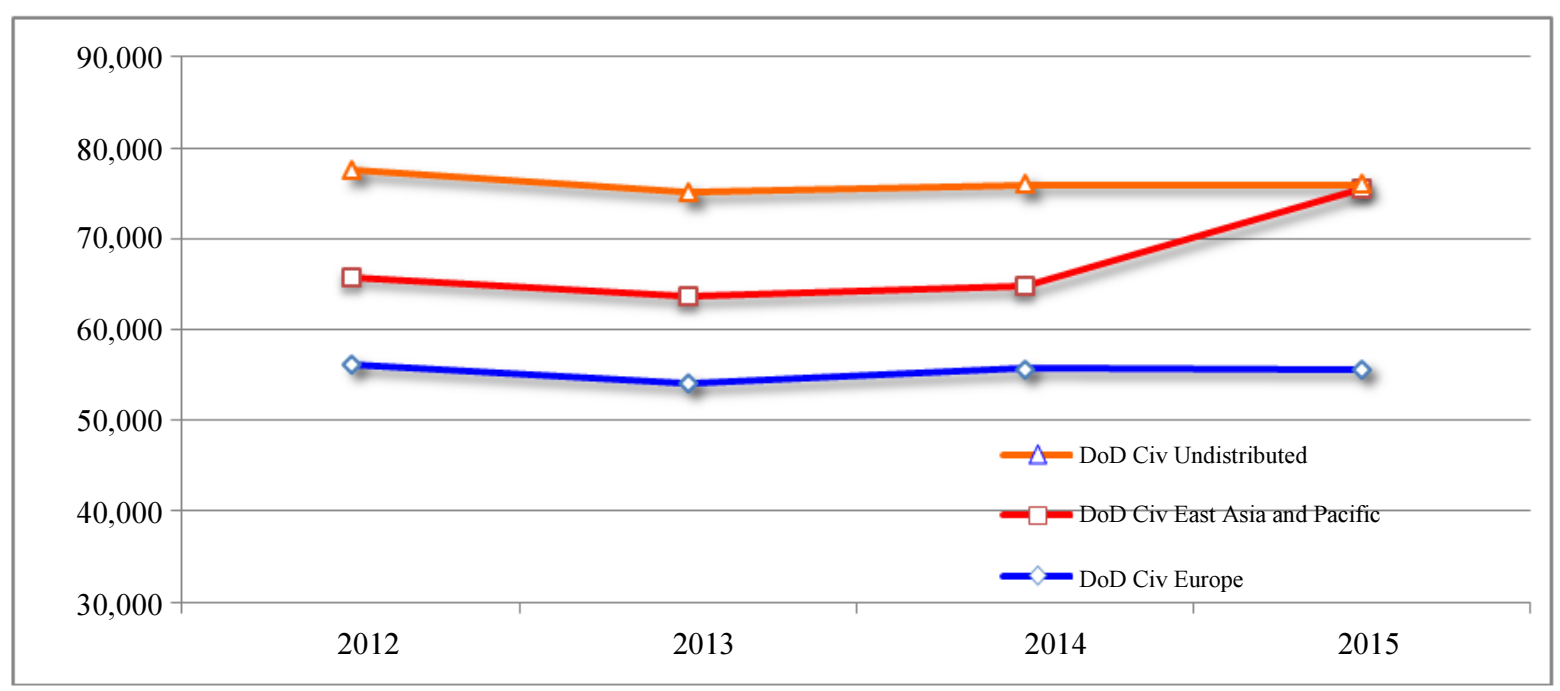

Fig. 9: DoD civilian end strength in Europe and Asia from 2012-2015 [Data source: Defense manpower data center]

Therefore, although total military end strength authorized by Congress has been reduced, one sees a slight relative increase in distribution of military personnel to the Asia-Pacific region, an outcome that provides supporting evidence of military realignment coinciding with the timeframe of the pivot to Asia policy.

\section{Diplomatic Indicators}

Given the pivot to Asia was announced formally announced in writing by the Chief Diplomat, then Secretary of State Hillary Clinton, it is by all first appearances a diplomatic initiative. What might occur in the Obama administration's diplomatic sphere that would indicate such a pivot? As a singular occurrence, the restoration of diplomatic ties with Burma (Myanmar) in 2012 is particularly noteworthy. However, it does not necessary denote increased diplomatic engagement with the entire Asian region. To examine change in diplomatic focus and activity over time, diplomatic travel by both the President and by the Secretary of State can function as a consistent and measurable indicator. Although a rather broad measure, the purpose of examining foreign trips by such senior officials is twofold. First, the activity of senior executive leadership sets priorities for subordinate focus and activity within a government bureaucracy. A trip abroad by the President or the Secretary of State involves deep preparation on behalf of both the sending and receiving bureaucratic organizations, in terms of informational support, security and follow-up activities. Second, signaling is extremely important in matters of diplomacy. A foreign nation must agree to receive a U.S. senior official and both the 
sending and receiving sides rely on protocols and press releases to communicate the purpose and results of the exchange to domestic constituencies. Therefore, a foreign visit is a deliberate undertaking and is unlikely to occur unless the U.S. and a receiving nation wish to initiate, deepen, or maintain a diplomatic relationship.

For the purposes of this analysis, the international trip count of the President and Secretary of State is based upon destination tally even though multiple destinations are a part of a single international excursion. For example, a single presidential excursion lasting five contiguous days, arriving in Beijing with interim travel to Tokyo and departure from Moscow is counted as three trips, as the president has made diplomatic travel to three foreign nations.

Comparing the previous Bush administration with the Obama administration, former President George (2016) made 31 more international trips (140 total) than President Barack Obama (109 trips) [Fig. 10].
Further breaking down presidential trips into regional categories reveals that Obama has made slightly more trips to the Asian region than his predecessor-Bush made 22 trips; Obama has made 25 (Fig. 11). Expressed in terms of percentage, $23 \%$ of President Obama's total trips have been to the Asian region, versus $16 \%$ of George W. Bush's presidential trips.

Breaking out travel to the Asian region by country, Burma again stands out-President Obama travelled twice to Burma, coinciding with a renewal of diplomatic relations-whereas his predecessor made no trips the country. The same holds true for Malaysia, except diplomatic ties existed already. However, Bush made a single trip each to Mongolia and Pakistan, whereas President Obama has not travelled to those countries at all. Furthermore, President Bush made four trips to China during his presidency, one more than President Obama (Fig. 12).

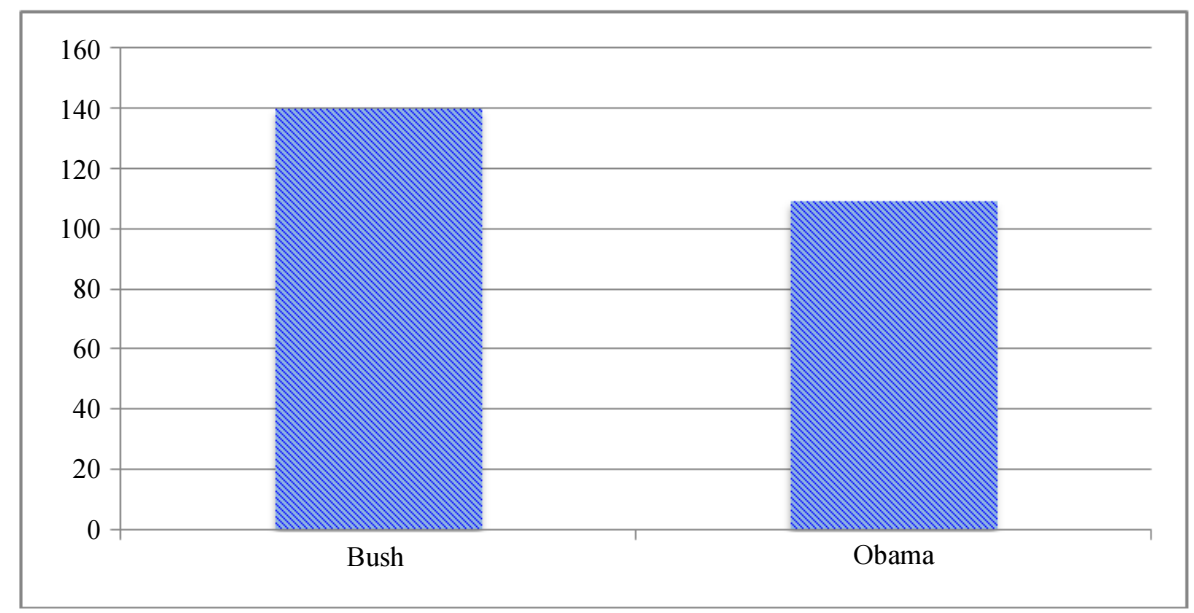

Fig. 10: Total international trips by Presidents George (2016) and Barack Obama [Data source: Office of the Historian, U.S. Department of State]

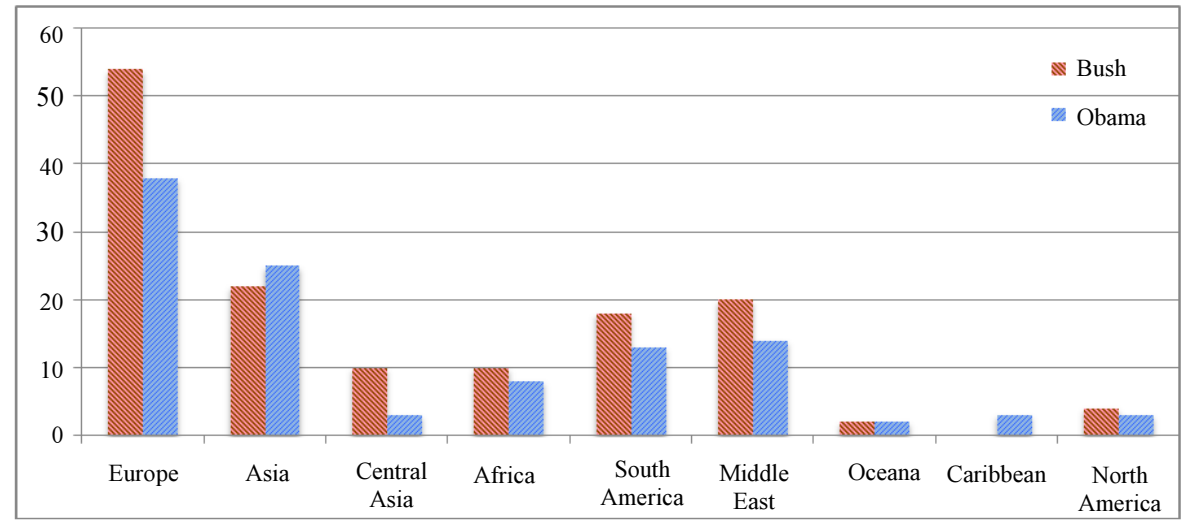

Fig. 11: International trips by George (2016) and Barack Obama, regional totals [Data source: Office of the Historian, U.S. Department of State] 


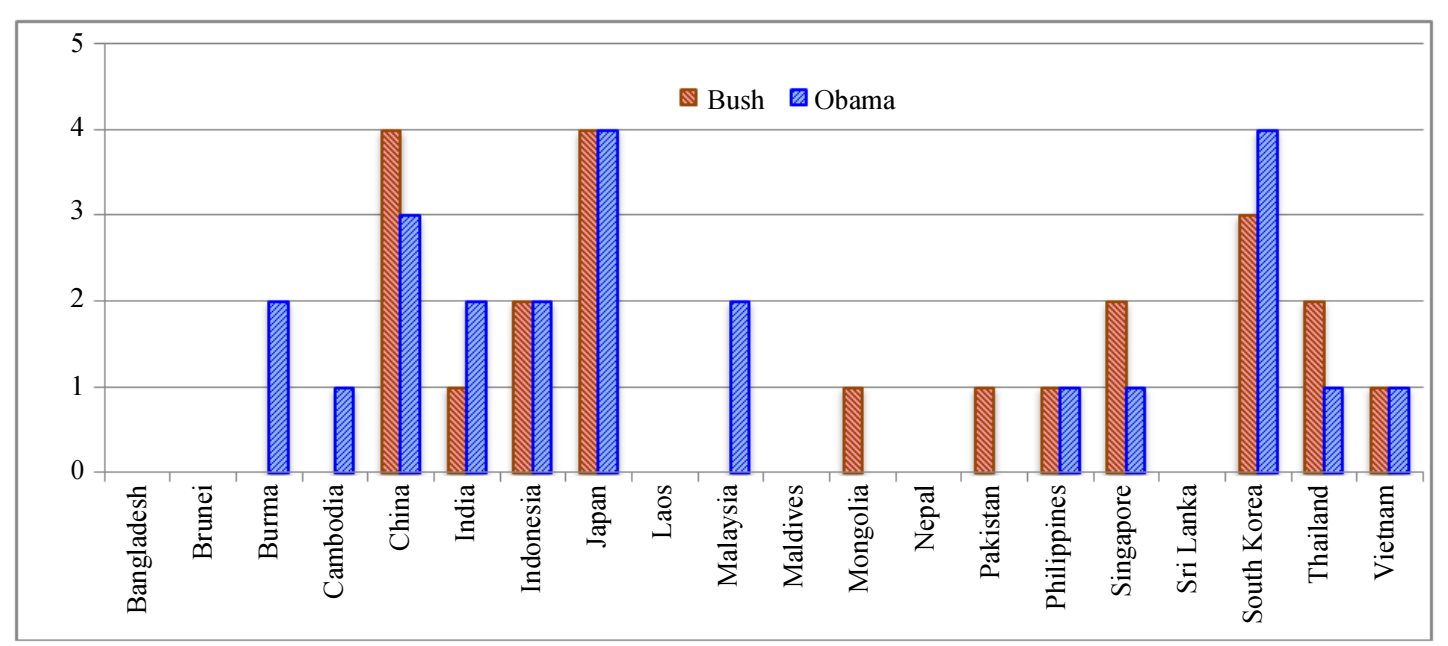

Fig. 12: Trips to Asia by Presidents George (2016) and Barack Obama, by country [Data source: Office of the Historian, U.S. Department of State]

Therefore, other than the fact that President Obama has had a higher percentage of presidential trips to Asia than his predecessor along with renewed ties with Burma, the there are no other particularly standout results from analyzing international presidential diplomatic travel.

Applying an identical analysis to the Secretaries of State of the last two presidential administrations involves examining a higher volume of travel distributed across four individuals, in chronological order: Colin Powell, Condoleeza Rice, Hillary Clinton, and John Kerry.

Of the four Secretaries of State, Kerry has made the most international trips: 342 total to date, with Rice coming in at second place with 274 total trips. Powell made the fewest international trips, 214, while Clinton had 239 (Fig. 13).

Broken down by region, all Secretaries of State made roughly the same number of trips to the Asian region; Kerry has made the most with 41 trips. The peak of the Iraq war is apparent in Rice's 100 trips to the Middle East; nonetheless she accomplished 33 trips to Asia, the same number as Clinton. Expressed in number of trips, Europe and the Middle East continue to receive more diplomatic visits than Asia (Fig. 14). From this perspective, an Asian pivot is not so evident.

Further analyzing travel to the Asian region by country, based on comparative trip count, one can observe a greater level of diplomatic engagement from the Obama administration with individual countries in the Asian region overall. Nepal and the Maldives are the only countries in the Asian region breakout analysis that received diplomatic travel from the George (2016) administration (via Powell), but have not received a visit from an Obama administration Secretary of State. Only South Korea received appreciably more attention in the Bush administration compared to the Obama administration, with 10 trips between Powell and Rice, versus four total trips between Clinton and Kerry. This volume most likely stems from diplomatic efforts concluding the bi-lateral United States-Korea Free Trade Agreement (KORUS FTA), signed in June 2007.

China's steadily increasing global influence is evident in the diplomatic attention it has received. Starting with Colin Powell in 2000, China received five trips, another six with Rice, seven with Clinton and escalating to 13 with Kerry, marking 20 total trips for the Obama administration to date as compared with 11 total for the Bush administration. Conversely, Japan's visit count has decreased slightly, from 10 total visits during the Bush administration to seven during Obama's presidency (Fig. 15).

The diplomatic engagement with smaller countries in the Asia-Pacific region is certainly noteworthy. Burma stands out once again with six trips-Clinton took two trips and Kerry has taken four trips coinciding with the Obama administration's renewal of diplomatic relations with the country in 2012. Vietnam received literally over three times the amount of diplomatic consideration from the Obama administration with seven total trips, compared to two visits from the Bush administration. The same is nearly the case for Singapore, with two visits from Bush administration Secretaries of State, compared with five total from the Obama administration. Cambodia received four times as many visits during Obama's presidency compared to his predecessor, with three visits from Clinton alone. Trips to Malaysia doubled during the Obama Presidency to a total of four and trips to Brunei increased from one to three.

In conclusion, analysis reveals that that Obama administration has indeed stepped up diplomatic activity to Asia in the years since the Asian pivot announcement, with notable increases in diplomatic attention to Burma, Cambodia, Singapore, Malaysia and Vietnam. 


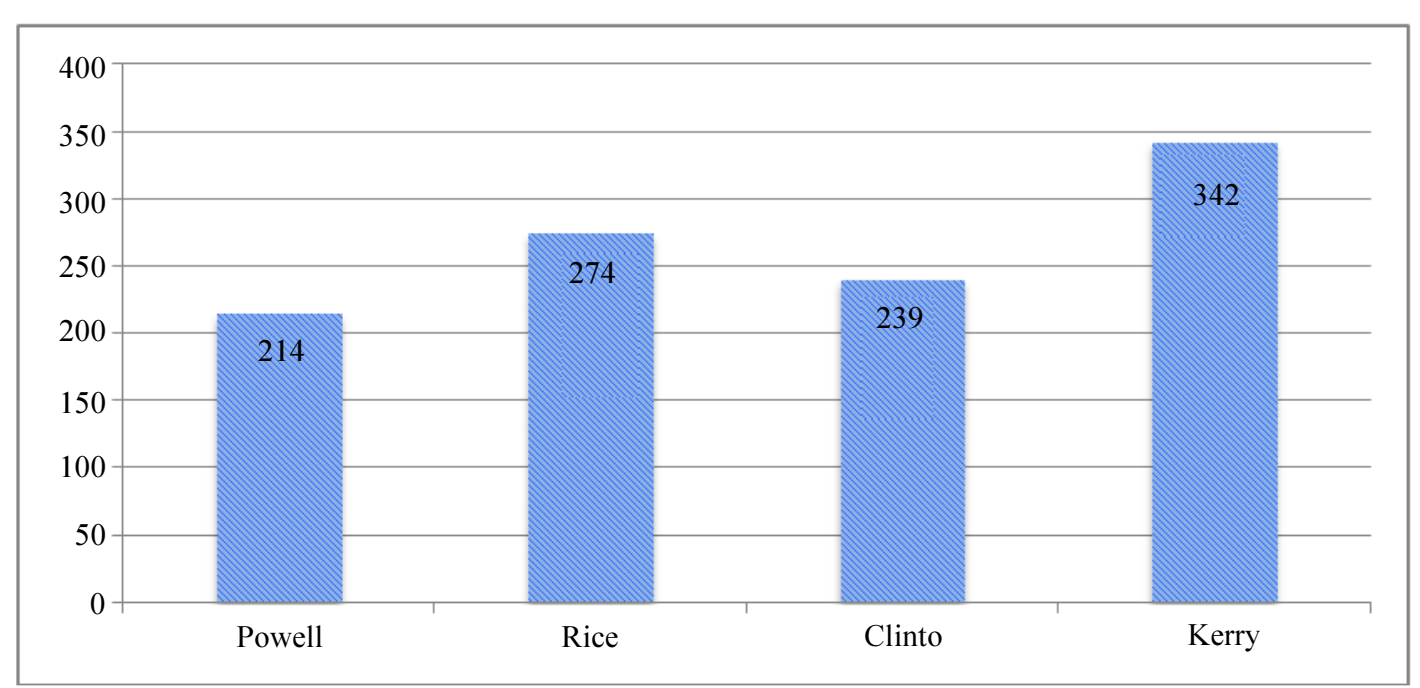

Fig. 13: Total international trips by Secretaries of State since 2000 [Data source: Office of the Historian, U.S. Department of State]

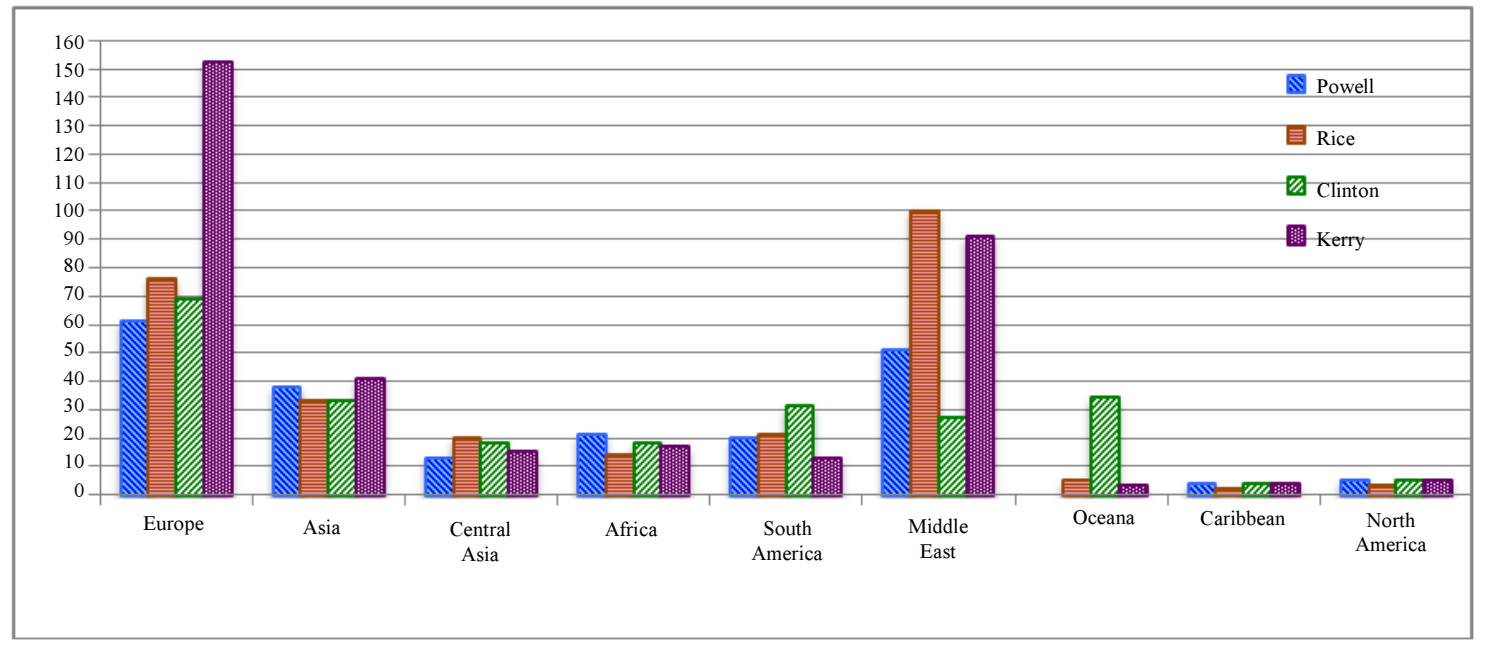

Fig. 14: International trips by Secretaries of State since 2000, by region [Data source: Office of the Historian, U.S. Department of State]

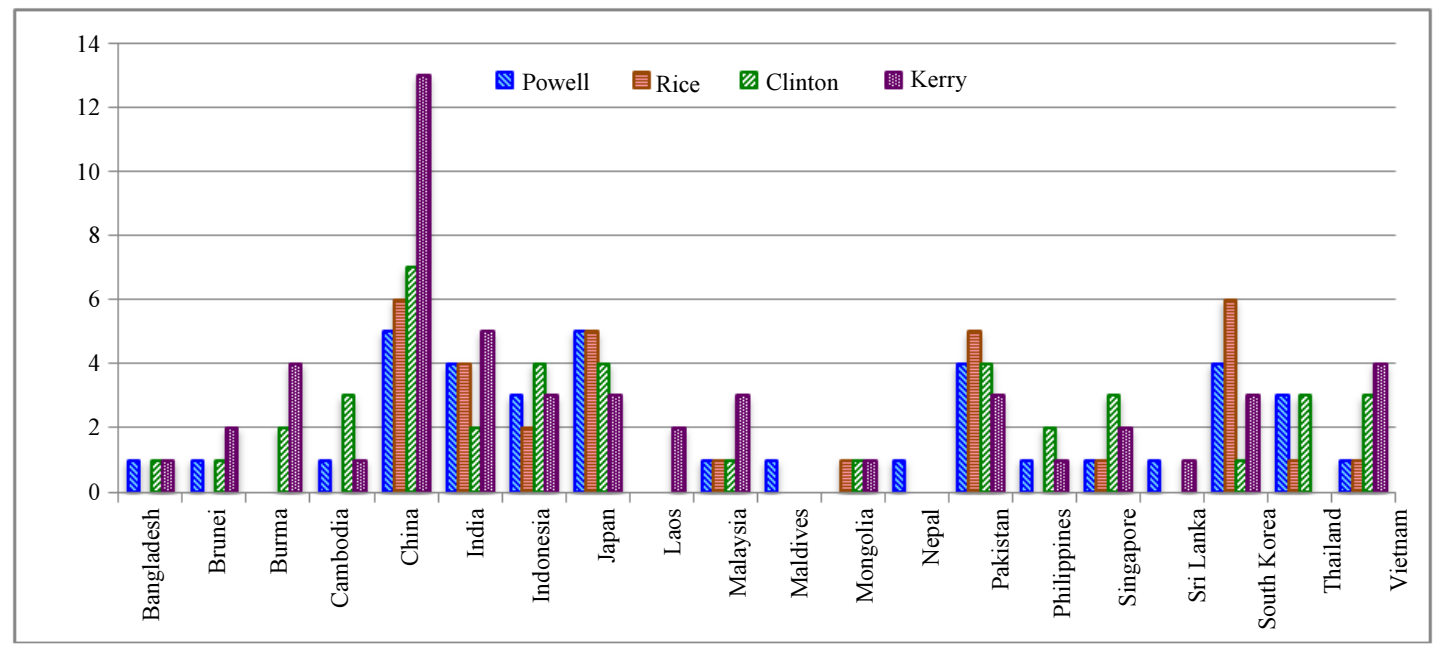

Fig. 15: Trips to Asia by Secretaries of State since 2000, by country [Data source: Office of the Historian, U.S. Department of State)] 


\section{Discussion}

The preceding economic, diplomatic and military indicators clearly suggest a pivot to Asia is in progress, in response to both the increasing dominance of the Asia-Pacific in global trade and also to China's more assertive forays into contesting U.S.-led balance of power norms. Although none of the distinct actions taken in pursuit of the pivot demonstrate a drastic realignment of national power, the extent and effects of the U.S. pivot to Asia in aggregate are potentially farreaching in terms of global military and economic stability-that the U.S. has undertaken a pivot to Asia at all signals its desire to maintain hegemonic influence in the Pacific, rather than cede influence to competitors.

With an Executive Branch transition of power imminent in January of 2017, the contours of the inprogress Asian pivot could change along with the incoming presidential administration. However, the U.S. has a large professional bureaucracy well practiced at executing sustained policy initiatives across presidential administrations; the policy of containment during the Cold War is an excellent example. Although the specific diplomatic, economic and military engagements falling under the "containment" designation evolved over time, the core strategy of the initiative-prevent the spread of communism and check the expansionist dominance of the Soviet Union for the purposes of maintaining U.S. hegemonic power-did not change over thirty years until the collapse of the Soviet Union.

Military issues by nature of urgency attract attention, but slower moving diplomatic and trade efforts also merit evaluation. Historically, U.S. engagement with nations as in the Asian region has skewed strongly toward bilateral relations. During the Cold War, U.S. policy makers offered aid, imposed economic sanctions and engaged militarily on a nation-by-nation basis in Asia in pursuit of balance-of-power politics against the influence of communism as a competing economic system championed by the former Soviet Union. The categorical concept of a pivot or rebalance toward the Asia-Pacific acknowledges the region as a whole; it may represent the evolution of post-Cold War thinking toward an updated regional strategy aligned less against an ideological enemy, but more toward economic competitors pursuing realpolitik, mainly China to date, striving for strategic dominance and tilting global economic rules and norms more toward their individual national interests.

\section{Prospective Sources of Armed Conflict}

Overlapping territorial claims combined with historical assertions of national sovereignty combine to create geopolitical flashpoints in East Asia. Territorial disputes, being "zero-sum" in nature, are subject to fierce challenges since one state's gain is another state's direct loss. As outlined in this writing, Taiwan, the disputed territorial claims of the Senkaku Islands and North Korea as a nuclear state stand as the most prominent issues with potential to escalate toward armed conflict.

As China's greatest irredentist claim, Taiwan is conceivably the biggest wildcard when calculating potential U.S/Chinese military responses to alterations in the Asia-Pacific balance of power. Given its history as a Japanese colonial possession, a redoubt for Chinese revolutionary Chiang Kai Shek and the KMT, along with its current status as a democracy that has made a successful transition from the authoritarian KMT regime, the island is a potent symbol of defiance to contemporary PRC leaders who regard it as a renegade province. Leaders in the U.S. are well aware that China is surrounded by countries with the "motivation and ability to engage in balancing of their own should China start to build up an expansive military force." Diplomatic outreach by the Obama administration as a part of the Asian pivot clearly shows attempts to create new bilateral ties and strengthen existing relationships. For example, the administration took steps to normalize relations with Burma, as well as upgrading relations with Vietnam in a 2013 agreement to a "comprehensive partnership," opening the possibility of a deeper "strategic partnership."

Because of the One China Policy and the inherent threat an independent Taiwan poses to Chinese Communist Party credibility, Taiwan continues to be one of the most aggravating and sensitive topics for China; needless exacerbation of the Taiwan issue has strong potential to trigger a regional arms race if China decides to respond militarily. Based on recent indications, the U.S. will at best continue to reinforce a policy of strategic ambiguity regarding Taiwan and at worst, there is potential that an incoming Trump administration could use Taiwan as a bargaining chip. In a recent December 2016 interview, President-elect Donald Trump questioned continued U.S. observance of the "one China" policy, stating, "I fully understand the 'one China' policy, but I don't know why we have to be bound by a 'one China' policy unless we make a deal with China having to do with other things, including trade." His statement follows his accepting a telephone call almost two weeks earlier from Taiwan President Tsai Ing-wen, breaking nearly forty years of precedent since the Carter administration transferred official U.S. diplomatic recognition from Taiwan to the People's Republic of China in 1979. Although China has not responded militarily to the telephone call incident, which China's foreign minister dismissed as a "little trick," it swiftly lodged a formal diplomatic complaint with the U.S.

The territorial disputes in the East China and South China Seas represent another potential flash point for military conflict. Although China has reduced considerably the frequency of its incursions into territorial waters around the Japanese-claimed Senkaku 
Islands, it still makes consistent patrols and continues to claim an Air Defense Identification Zone that covers the landmasses. It would take very little effort for China once again to intensify the frequency of incursions, which increases the potential for misunderstanding or mishap. Worst case, if tensions were to escalate to a naval battle, the U.S. could be brought into a Japanese conflict with China under U.S.-Japan Security Alliance, since the islands are under Japanese control. Likewise, a similar dynamic could occur in the South China Sea. China's claims of nearly the entire body of water run up against U.S. claims of freedom of maritime navigation. Furthermore, increased militarization, particularly on reclaimed land in the Spratly Islands, increases the odds of an escalating confrontation.

In the long term, as with former Warsaw Pact nations, careful military-to-military exchange as well as cross-cultural military education could further U.S. cultural impact, with the goal of encouraging the evolution of the Chinese military from a party apparatus to one accountable to the civilian population and more in sync with U.S. democratic ideals. The U.S. has taken this route in inviting China to participate along with Japan and 24 other nations in the U.S-staged Rim of the Pacific (RIMPAC) military exercises, first in 2014 and again in 2016. Also, such peaceful military interaction increases each nation's understanding of each other's naval operations and capabilities, thus reducing the potential of misinterpreting future friendly maneuvers as adversarial, as well as advertising deterrent military capabilities.

China has thus far withheld the use of hard power to resolve its territorial claims and would do well to continue steadily and cautiously-it waited a century for Hong Kong's reunification with Mainland China and a similar strategy in relation to Taiwan would allow for a gradual shift in the balance of power. As President Tsai Ing-wen's telephone call to Donald Trump illustrates, China is not the only actor and as unpredictable and even accidental events can occur, it will be important for all Pacific powers to maintain flexibility and moderation in response to almost certain infringement on individual nations' territorial and diplomatic preferences. Categorically, armed conflict is an option of last resortdespite tough talk, we see empirically that China, Japan, South Korea and the U.S. do not take the prospect of armed conflict lightly, as a shooting war does not appear imminent despite scuffles over sovereignty and contested territory. For example, South Korea unquestionably exercised restraint to what could be characterized as an act of war after the sinking of the warship Cheonan in 2010, which according to international experts, was the result of a North Korean torpedo attack. South Korea responded by cutting off trade to North Korea rather than by military retaliation.

Regarding China and its historic fears of invasion and encirclement, Kissinger reasons, "China can find reassurance in its own record of endurance and in the fact that no U.S. administration has ever sought to alter the reality of China as one of the world's major states, economies and civilizations." As analysis in this writing reveals, rather than directly confronting or blunting China's development, the pivot to Asia as a foreign policy strategy seeks to preserve U.S. hegemony and focuses military activities on maintaining a stable security environment for its allies in Asia and protecting right of passage through contested maritime environments, primarily the South China Sea.

Because of their singularly destructive force, nuclear weapons warrant specific mention. Outside of the U.S. alliance system in East Asia, China and North Korea maintain nuclear capability, with tiny North Korea adding the most uncertainty to the Asia-Pacific. Locked in place between nuclear-capable China to its north and U.S.-protected South Korea at its south, the U.S. relies on China to keep its unpredictable ally in check while remaining in a state of wartime readiness in South Korea. Although building and maintaining and effective conventional military force is expensive, acquiring nuclear weaponry is a fast-track method for an otherwise militarily disadvantaged state such as North Korea to increase its deterrent capabilities. The strategic effects of nuclear weapons, according to Grey, are a:

... counter-deterrent to the nuclear weapons of others. They also discourage the large-scale conduct of military operations of any kind because of the fear of accident, of inadvertent escalation, or even purposeful escalation once combat gathers momentum."

Therefore, in the Asia-Pacific, with nations such as Vietnam and South Korea confronting unresolved historical fears of invasion and China, in particular, pursuing regional hegemony, it is not difficult to imagine a nuclear arms race as individual nations seek the strategic deterring power of nuclear weaponry. "In 1969, Richard Nixon articulated the Nixon Doctrine, under which Americas allies should provide for their own defense with U.S. help and under the [so-called] U.S. nuclear umbrella." With U.S. allied nations of Japan and South Korea under the U.S. nuclear umbrella, Nixon sought to accomplish exactly the same objective as reaching out to China-"... stable international order for a world filled with nuclear weapons." Notably, just as probability of confrontation along with the negative costs of potential strategic miscalculation increase in a conventional military buildup, when nuclear arms are involved, the costs of miscalculation in the event of a confrontation rise exponentially.

All parties in the Asia-Pacific most certainly recognize that armed conflict directly and negatively affects global trade, which, although important to any nation, is the absolute lifeblood of the export-driven Chinese economy. Further, sustained aggression, as in the case of North Korea, clearly provides incentives for allied nations to explore economic sanctions as a 
deterrent; once again, a potential future consequence that would be most severe for China given its reliance on export markets. An arms race in Asia would be the utmost expensive route to attempt to resolve balance of power and territorial disputes, as there is no guarantee that any one nation would come out on top and in the case of a nuclear proliferation, everyone would lose.

\section{Can the Pivot Prevail?}

The stability provided by regional multilateral institutions, such as NATO in Europe, is instructive for future relations with the Asia-Pacific. Although the future of TPP is uncertain, its strategic benefits will no doubt give the incoming Trump administration pause for review, as it provides the U.S. a head start in developing a broad-ranging set of economic and trade rules to establish norms in the Asia-Pacific. Further, should TPP go into effect, its combination of diplomatic and economic features could provide the foundation for a future multilateral security organization in Asia (notably, the European Union, for all of its contemporary problems, evolved from a simple post World War II economic union). Such a multilateral entity would ease the singular burden placed on the U.S. to resolve grievances that currently tend to play out as the United States (often via an ally) as an arbiter against China. With China's historical fears encirclement and inclination to assume conspiratorial victimization by outside powers, a transparent multilateral approach to dispute resolution would perhaps aid in diffusing the ire frequently directed by China at the United States. With its current web of bilateral alliances, the U.S. manages "a delicate balancing act," as "... it must communicate enough resolve so as to discourage aggression against its friends and allies, but it must avoid signaling unconditional support (the diplomatic version of moral hazard) lest it encourage those friends and allies to behave provocatively or recklessly." Observing China's island building and continued militarization in the South China Sea, along with its consistent incursions into Japanese territory in the East China Sea, the possibility of the U.S. getting pulled into a regional skirmish by an emboldened ally is quite real. Therefore, a future multilateral security alliance, as demonstrated by NATO, would be ideal. In the interim, increased Chinese militarization will most likely strengthen existing bilateral alliances and provide incentives for smaller states, like Vietnam and Burma, to evaluate looking to the U.S. for potential security arrangements.

Assuming "... U.S. primacy is the core means of achieving American national security and maintaining regional peace, the only acceptable outcome is Chinese acquiescence in a U.S.-led security order." Thus far, China has exhibited willingness to begin challenging a U.S.-led order through its persistent actions in the East China and South China Seas, with the emergence of the pivot policy a reflection of this new reality. The logic of invoking past U.S. policies of containment when exploring contemporary U.S. relations with China breaks down upon recognition that China, to date, has not pursued global expansionism of its political system. However, assuming the U.S. will continue vying with China to maintain ongoing hegemony in the international system, that is, competition in creating and enforcing rules and norms, some lessons learned during the execution of containment strategies over time are arguably relevant. Again, using Cold War as an example, the U.S. strategy of containment did not directly defeat the Soviet Union; the Soviet Union in essence collapsed under systemic pressures originating from within its own domestic political system. Likewise, any future policy iterations of a sustained Asian pivot are unlikely on their own to prevail as singular mechanisms for maintaining U.S. hegemony; as experience with the Soviet Union has shown, the U.S. has time on its side.

Notably, China faces its own substantial endogenous political pressures. As much as perpetual U.S. hegemony is not certain, the continued economic growth and stability of China is not guaranteed, either. China, in the aggregate, has much more work to do. According to Meyer (2015), China faces a "triple dependency on natural resources, technology and markets overseas." Self-sufficient only in coal and highly reliant on exports based on foreign technology for its economic growth, China must import ever increasing amounts of energy and commodities. Other than investing in military growth and building civil infrastructure such as rail, roads and bridges, China's obstacle in the intermediate term is to transition from an export-led economy dependent on foreign investment to an economy that can create internal consumption and development. A large a part of this task is building viable institutions that can flexibly support complex economic exchange. In the U.S., institutional structures such as the Federal Reserve and a system of courts that have been in place for generations work so smoothly that their existence can become taken for granted. The basic institutional mechanisms employed by U.S. businesses and individual citizens to hedge against risk are virtually non-existent in China: there is no nation-wide system of credit, no system of property or personal insurance, no comparative system of personal property rights or reliable courts to provide dispute adjudication. Although the flow of U.S. dollars into China has reached record levels, as an empirically observed fact, no amount of money can create social stability created by liberal democratic institutions. For example, "when the SARS epidemic hit in 2003, China discovered that it utterly lacked a functioning public health system in rural areas."

In addition to sparse institutional frameworks, natural resource constraints are ever present in China. By the power of small numbers, any slight rise in the living standards across the Chinese population of over one 
billion people will not only require immense resources, but will place very real constraints on production and consumption. China must negotiate natural resource scarcity as it grows; even small changes in consumption multiplied by the whole population can have incredible net results. Considering a basic resource such as water, per capita China has about one-third the world average of renewable water resources. As living standards have increased, the rate of overall resource consumption within China has not been sustainable.

Finally, China also faces real demographic constraints, which could prove to be its biggest challenge of all. Its One Child Policy “... is a double-edged sword ... the low birth rate has contributed to the overall aging of the population-an estimated 11.8 percent of China's population will be 65 or older by 2020 " China's workforce-citizens aged 15-59-peaked in 2011 and has already begun to decline. With such a large percentage of its population reaching old age so rapidly, shifts in domestic policy along with decreasing productivity are highly likely. At the beginning of the 1990s, Japan began negotiating a very similar adjustment, albeit on a smaller scale than in China. “... [A] low birth rate and a rapidly ageing population meant that most Japanese had to turn away from high consumption and conserve their yen for retirement." With an even greater percentage of its population ageing more rapidly, combined with the urgent need to develop greater consumption from within its own economy in order to reduce reliance on exports, its quite possible that "... China could find itself old before it gets rich." Therefore, according to Kissinger, when compared to the U.S., China faces the enormous endogenous tasks of managing a ... population that is four times as large, aging and engaged in complex domestic transformations occasioned by China's growth and urbanization. The practical consequence is that a great deal of China's energy will still be devoted to domestic needs.

In the face of such pressures, there is an ongoing threat to domestic perceptions of the ruling Chinese Communist Party's legitimacy. It has the formidable task of maintaining rising living standards, for which the Chinese people have implicitly exchanged their individual freedoms in consent of the one party state, simultaneous to managing external threats and pressures in the realm of foreign affairs without appearing weak or ineffective. The Communist Party bases its legitimacy on the notion that alternatives to the current regime would invite lower living standards as a result of chaos and disorder. However, should the Communist Party insufficiently maintain rising living standards, the logic of its legitimacy falls apart, especially in comparison to the growth and prosperity promulgated by foreign democratic governing institutions in Asia itself, such as Japan, South Korea and particularly, Taiwan.
Consequently, prospects that China will pursue an expansionist agenda in East Asia are unlikely as its leadership faces substantial domestic economic, social and political pressures. Continued U.S. rebalancing to the Asia Pacific must take China's domestic limitations into consideration in order to leave room for compromise or evolution on Chinese policy to achieve peaceful resolution of complicated issues and avoid blowups that raise the risk of escalating conflict (like the 1995 Taiwan Straits Crisis). For example, although future disagreements are inevitable, it will be important for U.S. leadership to anticipate future confrontations and manage China's challenges to free right of maritime passage in a firm yet balanced manner. Doing so would attempt to avoid unduly escalating petty skirmishes into perceived foreign threats to Communist Party legitimacy as it manages the stresses of domestic concerns.

\section{Materials and Methods}

Materials and Methods should be described with sufficient details to allow others to replicate and build on published results. Please note that publication of your manuscript implicates that you must make all materials, data, computer code and protocols associated with the publication available to readers. Please disclose at the submission stage any restrictions on the availability of materials or information. New methods and protocols should be described in detail while well-established methods can be briefly described and appropriately cited.

Research manuscripts reporting large datasets that are deposited in a publicly available database should specify where the data have been deposited and provide the relevant accession numbers. If the accession numbers have not yet been obtained at the time of submission, please state that they will be provided during review. They must be provided prior to publication.

Interventionary studies involving animals or humans and other studies require ethical approval must list the authority that provided approval and the corresponding ethical approval code.

\section{Conclusion}

Encompassing diverse activities across elements of national power, the pivot to Asia is clearly in progress; its very existence signals U.S. resolve to continue exercising hegemonic influence and play a dominant role in shaping Asia-Pacific affairs as it has throughout the last century. Consistent with U.S. historical precedent, analysis reveals that the pivot is not overly ambitious or expansionist in terms of military growth or in economic shift and is largely focused on maintaining balance of power and preserving access for trade (although future administrations could of course push the policy to evolve and take a more aggressive posture). However, any shift or rebalance of limited resources cannot occur in 
perpetuity; therefore, at some point in the near future, the Pivot to Asia policy initiative, as a rebalancing of focus and resources, will come to a point of termination when the elements of U.S. national power currently under adjustment (diplomatic, economic and military) have reached their logical ends.

China will continue to assert its maritime claims and the U.S. will face the challenge of balancing the military component of its pivot with a sustainable economic strategy allowing it to diversify supply chains away from China to other nations in the Asia-Pacific, thus blunting China's established propensity to leverage economic coercion. Although trade agreements have their discontents, TPP represents the most viable opportunity for the U.S. to participate in and lead a trading bloc enabling multilateral balance of power in the Asia-Pacific and most likely extending U.S. hegemony.

Lastly, recognizing that the pivot to Asia is a response to China's challenging U.S. hegemony in Asia, U.S policy makers would be wise to take the long view. In the 1980s, Japan's export-fueled economic growth and increasing economic power generated considerable anxiety in the U.S. about losing global dominance; by 1991 Japan entered into recession and began a period of stagnation known as the "lost decade," ushering in a period of domestic social upheaval that upended Japan's upward trajectory as an economic juggernaut. If current trends continue, based on China's internal resource and demographic constraints alone, its ability to contest international norms and U.S. hegemony will most certainly face limitations. Thus, the U.S. would be wise to follow Deng Xiaoping's strategy from over thirty years ago: "bide our time and build our capabilities."

\section{Author Contributions}

Authorship has been limited to those who have contributed substantially to the work reported.

Lucas Bittick: Conceived and designed the research and wrote the draft.

Timothy Sands: Analyzed the data, assembled the manuscript and managed peer review.

\section{Conflicts of Interest}

The authors declare no conflict of interest.

\section{References}

ABC News, 2001. Plane Leaves Hainan with Spy Plane Crew. http://abcnews.go.com/International/story?id=812 $48 \&$ page $=1$.

BBC News, 2016. TPP: What Is It and Why Does It Matter? 32498715
Center for International and Strategic Studies, 2016. Infographic: US Military Personnel in East Asia. In Asia Maritime Transparency Initiative, https://amti.csis.org/atlas/, 2016

LexisNexis ${ }^{\circledR}$ Academic, 2015. All News' Query. http://academic.lexisnexis.eu/

Armstrong, C.K., 2007. The Koreas Globalizing Regions Series. New York: Routledge.

Auslin, M.R., 2011. Pacific cosmopolitans: A cultural history of U.S.-Japan Relations: Harvard University Press.

Baker, K., M. Cooper, P. Heidlauf, T. Sands, 2018. Autonomous trajectory generation for deterministic artificial intelligence. Electrical Electronic Eng., 8: 59-68.

Blair, Bruce, C. Yali and E. Hagt, 2006. The oil weapon: Myth of China's vulnerability. China Security 2, no. 3: 32-63.

Blanchard, B. and M. Martina, 2016. China defends its right to 'Ready Slingshot' in South China Sea." Reuters News Agency http://www.reuters.com/article/us-southchinaseachina-idUSKBN1441DE

Blanchard, B., 2016. China lodges protest after trump call with Taiwan president. Reuters News Agency. http://www.reuters.com/article/us-usa-trump-taiwanidUSKBN13R2NT

Bohan, C., 2016. Trump Says U.S. Not Necessarily Bound by 'One China' Policy. Reuters News Agency. http://www.reuters.com/article/us-usatrump-china-idUSKBN1400TY

Brooks, S.G. and W.C. Wohlforth, 2002. American primacy in perspective. Foreign Affairs, 4: 20-33.

Burns, R.D., J.M. Siracusa and J.C. Flanagan, 2013. American foreign relations since independence. Santa Barbara, California: Praeger.

Byrne, B.T., 2006. The Rise of China and f America's grand strategic riposte. Carlisle Barracks, PA: U.S. Army War College.

Congressional Budget Office, 2007. Estimated Cost of the Administration's Proposal to Increase the Army's and the Marine Corps's Personnel Levels. Washington D.C.: Congress of the United States.

CBS News, 2012. U.S. To Restore Full Diplomatic Ties with Burma. http://www.cbsnews.com/news/us-torestore-full-diplomatic-ties-with-burma

Cha, V.D., 2010. Powerplay: Origins of the US Alliance System in Asia. International Security 34, 3: 158-196.

Chafe, W.H., 2015. The Unfinished Journey: America Since World War II. 8th Edn., New York: Oxford University Press.

Chang, G.G., 2015. China's self-inflicted demographic disaster is here. The National Interest. http://nationalinterest.org/feature/chinas-selfinflicted-demographic-disaster-here-14216. 
Chen, A.G., 1998. Taiwan's international personality: Crossing the river by feeling the stones. Loyola Los Angeles International Comparative Law J., 2: 223-255.

Central Intelligence Agency, 2016. Korea, North." In CIA World Factbook, Washington, D.C. https://www.cia.gov/library/publications/the-worldfactbook/geos/kn.html

U.S. Bureau of Labor Statistics, 2016. CPI Inflation Calculator. Washington D.C. http://data.bls.gov/cgibin/cpicalc.pl

Clinton, H.R., 2011. America's Pacific Century. Foreign Policy, 189: 56-63.

Combs, J.A., 2012. The History of American Foreign Policy from 1895. 4th Edn., Routledge, Armonk, New York, ISBN-10: 1317456416, pp: 560.

Cooper, M., P. Heidlauf and T. Sands, 2017. Controlling chaos-forced van der Pol equation. Mathematics, 5: 70-80. DOI: $10.3390 /$ math5040070

Defense Manpower Data Center, 2013. Total Military Personnel and Dependent End Strength by Service, Regional Area and Country. Washington D.C.: Department of Defense, 30 Jun 2013, \#P1306.

Defense Manpower Data Center, 2014. Total Military Personnel and Dependent End Strength by Service, Regional Area, and Country. Washington D.C.: Department of Defense, 30 Jun 2014, \#P1406.

Department of Defense, 2015a. The Asia-Pacific Maritime Security Strategy: Achieving U.S. National Security Objectives in a Changing Environment. Washington D.C.

Department of Defense, 2015b. Total Military Personnel and Dependent End Strength by Service, Regional Area, and Country. Washington D.C.: Department of Defense, 31 Mar 2015, DRS \#54601

Deng, Y., 2014. The Unwelcome Return: China Reacts to the US Strategic Pivot to Asia. In: The US Strategic Pivot to Asia and Cross-Strait Relations: Economic and Security Dynamics, Peter, C. and Y. Chow (Eds.), Palgrave Macmillan, New York, ISBN-10: 978-1-349-47344-1

Office of the Historian, 2016. Barack Obama. Presidential and Secretaries Travels Abroad, Department of State, Washington D.C.: U.S. https://history.state.gov/departmenthistory/travels/pr esident/obama-barack

Office of the Historian, 2016. Colin Luther Powell. Presidential and Secretaries Travels Abroad. Department of State, Washington D.C.: U.S. https://history.state.gov/departmenthistory/travels/se cretary/powell-colin-luther.
Office of the Historian, 2016. Hillary Rodham Clinton. Presidential and Secretaries Travels Abroad, Department of State, Washington D.C.: U.S. https://history.state.gov/departmenthistory/travels/se cretary/clinton-hillary-rodham.

Defense Manpower Data Center, 2012. Total Military Personnel and Dependent End Strength by Service, Regional Area, and Country. Washington D.C.: Department of Defense, 30 Jun 2012, \#P1206.

Dollar, David, 2005. China's Economic Problems [and Ours]. The Milken Institute Review, no. 3rd Quarter (2005): 48-58.

Domonoske, Camila. 2016. Beijing's Claims to South China Sea Are Invalid. International Tribunal Says. NPR News. https://goo.gl/TmzlI5

Drifte, R., 2014. The Japan-China confrontation over the Senkaku/Diaoyu Islands-between 'Shelving' and 'Dispute Escalation'. The Asia-Pacific J., 12: 1-59.

Office of the Historian, 2016. Condoleezza Rice." In Presidential and Secretaries Travels Abroad, Department of State, Washington D.C.: U.S. https://history.state.gov/departmenthistory/travels/se cretary/rice-condoleezza

Eckert, Paul, 2011. Clinton Declares 'America's Pacific Century. Reuters News Agency. http://goo.gl/drVu2k

Eckstein, Megan, 2016. SECDEF Carter: China Still Invited to RIMPAC 2016 Despite South China Sea Tension. USNI News. https://goo.gl/dIQxwe

Ford, C.A., 2015. China looks at the West: identity, global ambitions, and the future of Sino-American Relations. Asia in the New Millenium Series, Edited by Shiping Hua. Lexington, Kentucky: University Press of Kentucky.

Fravel, M.T., 2016. Explaining China's Escalation over the Senkaku (Diaoyu) Islands. Global Summitry, 1: 24-37.

Friedberg, A.L., 2005. The future of U.S.-China relations: Is conflict inevitable? Int. Security, 2: 7-45.

Gaddis, J.L., 2004. Surprise, security and the American experience. Cambridge: Harvard University Press.

Garver, J.W., 2016. China's Quest: The History of the Foreign Relations of the People's Republic of China. New York: Oxford University Press.

George, W.B, 2016. Presidential secretaries travels abroad. Department of State, Washington D.C., U.S. https://history.state.gov/departmenthistory/travels/pr esident/bush-george-w

Goto, S., 2013. "Introduction." In Clash of National Identities: China, Japan, and the East China Sea Territorial Dispute, edited by Tatsushi Arai, Shihoko Goto and Zheng Wang, 5-8. Washington D.C.: Wilson Center.

Gray, C.S., 1999. Modern Strategy. 1st Edn., Oxford University Press, Oxford. 
Green, M.J. and M.P. Goodman, 2016. After TPP: The geopolitics of Asia and the pacific. Washington Quarterly, 4: 19-34.

GlobalSecurity.org, 2016. Senkaku/Diaoyutai IslandsCompeting Claims. http://www.globalsecurity.org/military/world/war/se nkaku-claims.htm (2016)

Haass, R.N., 2013. The irony of American strategy. Foreign Affairs, 3: 57-67.

Heidlauf, P. and M. Cooper, 2017. Nonlinear lyapunov control improved by an extended least squares adaptive feed forward controller and enhanced luenberger observer. Proceedings of the International Conference and Exhibition on Mechanical and Aerospace Engineering, Oct. 2-4, Las Vegas, NV, USA.

Hixson, W.L., 2016. American Foreign Relations: A New Diplomatic History. 1st Edn., Routledge, New York, ISBN-10: 1135021104, pp: 486.

Ibe, H., 1992. Japan thrice-opened. Praeger, New York.

Office of the United States Trade Representative. TransPacific Partnership." In Initiatives, Washington, D.C. https://ustr.gov/tpp/

Office of the Historian, 2016. "John Forbes Kerry." In Presidential and Secretaries Travels Abroad, Washington D.C.: U.S. Department of State, https://history.state.gov/departmenthistory/travels/se cretary/kerry-john-forbes.

Kissinger, H., 1994. Diplomacy. 1st Edn., Simon and Schuster, New York, ISBN-10: 1471104494, pp: 912.

Kissinger, H., 2012. The future of U.S.-Chinese relations: Conflict is a choice, not a necessity. Foreign Affairs, 2: 44-55.

Kissenger, H., 2014. World Order. 1st Edn., Penguin Press, New York, ISBN-10: 0698165721, pp: 432.

Kissenger, H., 2011. On China. 1st Edn., The Penguin Press, New York, ISBN-10: 0141972386, pp: 624.

Kissenger, H., 2019. China: Containment won't work. Washington Post.Korea, South, 2016. Korea, South. CIA World Factbook, Washington, D.C. https://www.cia.gov/library/publications/the-worldfactbook/geos/print_ks.html

Lacey, J., 2016. Great Strategic Rivalries: From the Classical World to the Cold War. 1st Edn., Oxford University Press, ISBN-10: 0190620463, 662.

Lai, D., 2009. Chinese military going global. China Security, 1: 3-9.

Lobo, K., J. Lang, A. Starks and T. Sands, 2018. Attitude control amidst mass inertia modifications and orbital disturbances. Int. J. Control Sci. Eng., 8: 53-62.

Malchow, H.L., 2016. History and International Relations: From the Ancient World to the 21st Century. 1st Edn., Bloomsbury, London, ISBN-10: 1441106251, pp: 344.
Martel, W.C., 2015. Grand Strategy in Theory and Practice: The Need for an Effective American Foreign Policy. 1st Edn., Cambridge University Press.

McDevitt, M.A., C.K. Lea, A.M. Denmark, K.E. Gause and B.S. Glaser et al., 2012. East China and Yellow Seas. In: The Long Littoral Project: A Maritime Perspective on Indo-Pacific Security, CAN, Alexandria.

McDevitt, M.A., M.T. Fravel and L.M. Stern, 2013. South China Sea. In: The Long Littoral Project: A Maritime Perspective on Indo-Pacific Security, CAN, Alexandria.

Mearsheimer, J.J., 2006. China's unpeaceful rise. Current History, 690: 160-162.

Meyer, C., 2015. Economic and Strategic Leadership in Asia: The Rivalry between China and Japan. In: Japan: The Precarious Future, Frank, B. and A. Allison (Eds.), New York University Press, New York, pp: 261-281.

Mihalik, R., H. Camacho and T. Sands, 2017a. Continuum of learning: Combining education, training and experiences. Education, 8: 9-13. DOI: $10.5923 /$ j.edu. 20180801.03

Mihalik, R., H. Camacho and T. Sands, 2017b. Education in nuclear deterrence and assurance. J. Def. Manage., 7: 166-166. DOI: 10.4172/2167-0374.1000166.

Miller, J.H., 2014. American Political and Cultural Perspectives on Japan: From Perry to Obama. 1st Edn., Lexington Books, Lanham, Maryland, ISBN10: $0739189131, \mathrm{pp}: 184$.

Moore, G., 2015. Defining and Defending the Open Door Policy: Theodore Roosevelt and China. 1st Edn., Lexington Books, Lanham, Maryland, ISBN10: 073919996X, pp: 252.

Murphy, R.T., 2015. Japan and the Shackles of the Past. 1st Edn., Oxford University Press, New York, ISBN-10: 0199845980, pp: 443.

Mihalik, R., H. Camacho and T. Sands, 2017. Continuum of learning: Combining education, training and experiences. Education, 8: 9-13. DOI: $10.5923 /$ j.edu.20180801.03

Nakatani, S. and T. Sands, 2014. Simulation of spacecraft damage tolerance and adaptive controls. Proceedings of the IEEE Aerospace Conference, Mar. 1-8, IEEE Xplore Press, pp: 1-16. DOI: 10.1109/AERO.2014.6836260

Nakatani, S., 2016. Autonomous damage recovery in space. Intl. J. Auto. Contr. Intell. Sys., 2: 22-36. Nakatani, S., 2018a. Battle-damage tolerant automatic controls. Elec. Electr. Eng., 8: 10-23. DOI: $10.5923 /$ j.eee. 20180801.02 
Nakatani, S., 2018a. Battle-damage tolerant automatic controls. Elec. Electr. Eng., 8: 10-23. DOI: $10.5923 /$ j.eee. 20180801.02

Nakatani, S., 2018b. Timothy sands, eliminating the existential threat from North Korea. Sci. Technol., 8: 1-16. DOI: 10.5923/j.scit.20180801.02

Nathan, A.J. and A. Scobell, 2015. China's Search for Security. 1st Edn., Columbia University Press, New York, ISBN-10: 0231140517, pp: 432.

Neely, C.J., 2016. Chinese foreign exchange reserves and the U.S. Economy. Economic Synopses Federal Reserve Bank St. Louis., 9: 1-2.

BBC News, 2015. North Korea: 'No Apology' for S Korea Cheonan Sinking. http://www.bbc.com/news/world-asia-32013750

New Zealand Foreign Affairs and Trade, 2016. TransPacific Strategic Economic Partnership (P4). In Free Trade Agreements in Force, Wellington, New Zealand. https://www.mfat.govt.nz/en/trade/freetrade-agreements/free-trade-agreements-in-force/p4/

Office of the Secretary of Defense, 2016. Annual Report to Congress: Military and Security Developments Involving the People's Republic of China. 117FA69.

Oshima, T. and K. Minemura, 2012. Panetta tells china that senkakus under Japan-U.S. security treaty. Asahi Shimbun.

http://ajw.asahi.com/article/asia/china/AJ201209210 061

Office of the United States Trade Representative, 2016. New Opportunities for U.S. Exporters under the U.S.-Korea Trade Agreement. In Free Trade Agreements, Washington, D.C. https://ustr.gov/trade-agreements/free-tradeagreements/korus-fta.

Gaddis, J.L., 2005. Strategies of Containment. Oxford: Oxford University Press, 2005.

Packard, G.R., 2010. Some thoughts on the 50th Anniversary of the US-Japan security treaty. AsiaPacific Rev., 2: 1-9.

Park, K., 2016. Image: Territorial claims in the South China sea. Beijing's Claims To South China Sea Are Invalid, International Tribunal Says, NPR News, Washington D.C. https://goo.gl/TmzlI5

Patrick, S., 2009. The Best Laid Plans: The Origins of American Multilateralism and the Dawn of the Cold War. Lanham, Maryland: Rowman and Littlefield.

Perlez, J., 2012. Philippines and China Ease Tensions in Rift at Sea. The New York Times https://goo.gl/bCtQtg

Rodrik, D., 2006. What's so special about China's exports? National Bureau of Economic Research, Cambridge, MA.

Ross, R.S., 2015. China. In: Isolate or Engage: Adversarial States, US Foreign Policy and Public Diplomacy, Geoffrey, W. (Ed.), Stanford University Press, Stanford, California.
Roy-Chaudhury, S., 2016. The Senkaku Islands dispute. International Policy Digest. https://intpolicydigest.org/2016/08/01/senkakuislands-dispute/.

Ryan, D., 2000. US foreign policy in world history. Routledge, London.

Sachs, J., 2005. The End of Poverty: Economic Possibilities for Our Time. 1st Edn., Penguin Press, New York, ISBN-10: 0143036580, pp:397.

Sands, T. and C. Armani, 2018. Analysis, correlation and estimation for control of material properties. J. Mech. Eng. Auto., 8: 7-31.

DOI: $10.5923 /$ j.jmea.20180801.02.

Sands, T. and R. Mihalik, 2016. Outcomes of the 2010 and 2015 nonproliferation treaty review conferences. World J. Soc. Sci. Humanities, 2: 46-51.

DOI: 10.12691/wjssh-2-2-4

Sands, T. and R. Mihalik, 2018. Theoretical context of the nuclear posture review. J. Soc. Sci., 14: 124-128. DOI 10.3844/jssp.2018.124.128

Sands, T. and T. Kenny, 2017. Experimental piezoelectric system identification. J. Mech. Eng. Auto., 7: 179-195. DOI: 10.5923/j.jmea.20170706.01.

Sands, T., 2007. Fine pointing of military spacecraft. Ph.D. Thesis, Dissertation, Naval Postgraduate School, Monterey, CA, USA.

Sands, T., 2009a. Robert Lorenz, physics-based automated control of spacecraft. Proceedings of the AIAA Space Conference and Exposition, (SCE' 09), Pasadena, CA, USA, pp: 14-17.

Sands, T., 2009b. Satellite electronic attack of enemy air defenses. Proceeding of the IEEE Southeastcon, Mar. 5-8, IEEE Xplore Press, Atlanta, GA, USA, pp: 434-438. DOI:10.1109/SECON.2009.5174119

Sands, T., 2012. Physics-Based Control Methods. In: Advances in Spacecraft Systems and Orbit Determination, Ghadawala, R. (Ed.), InTech, London, ISBN-10: 9535103806.

Sands, T., 2015. Improved magnetic levitation via online disturbance decoupling. Phys. J., 1: 272-280.

Sands, T., 2016. Strategies for combating Islamic state. Soc. Sci., 5: 39-39. DOI: 10.3390/socsci5030039.

Sands, T., 2017a. Nonlinear-adaptive mathematical system identification. Computation, 5: 47-59. DOI: $10.3390 /$ computation5040047

Sands, T., 2017b. Phase lag elimination at all frequencies for full state estimation of spacecraft attitude. Phys. J., 3: 1-12.

Sands, T., 2017c. Space systems identification algorithms. J. Space Expl., 6: 138-149.

Sands, T., 2017d. The catastrophe of electric vehicle sales. Mathematics, 5: 1-46.

Sands, T., 2018a. Electric vehicle sales catastrophe averted by deterministic artificial intelligence methods. Draft Manuscript Submission. 
Sands, T., 2018b. Experimental sensor characterization. J. Space Explorat., 7: 1-140.

Sands, T., 2018c. Space mission analysis and design for electromagnetic suppression of radar. Intl. J. Electromag. Apps., 8: 1-25. DOI: $10.5923 /$ j.ijea.20180801.01.

Sands, T., 2019a. Advances in Spacecraft Attitude Control. Forthcoming as Stanford University, ISBN: 978-1-78984-802-1.

Sands, T., 2019b. Deterministic Artificial Intelligence. Forthcoming as Stanford University, ISBN : 978-178984-111-4.

Sands, T., B. Agrawal and J. Kim, 2018a. Singularity Penetration with Unit Delay (SPUD). Mathematics, 6: 23-38. DOI: 10.3390/math6020023

Sands, T., D. Lu, J. Chu and B. Cheng, $2018 \mathrm{~b}$. Developments in angular momentum exchange, Int. J. Aerospace Sci., 1: 1-7. DOI: $10.5923 /$ j.aerospace.20180601.01.

Sands, T., H. Camacho and R. Mihalik, 2018c. Nuclear posture review: Kahn Vs. Schelling and perry. J. Soc. Sci. 14: 145-154. DOI: $10.3844 /$ jssp.2018.145.154

Sands, T., K. Bollino, I. Kaminer and A. Healey, 2018d. Autonomous minimum safe distance maintenance from submersed obstacles in ocean currents. J. Mar. Sci. Eng., 6: 98. DOI: 10.3390/jmse6030098

Sands, T. and K. Bollino, 2018. Autonomous Underwater Vehicle Guidance, Navigation and Control. In: Autonomous Vehicles https://www.intechopen.com/onlinefirst/autonomous -underwater-vehicle-guidancenavigation-and-control

Sands, T., J. Kim and B. Agrawal, 2006. 2H SingularityFree Momentum Generation with Non-Redundant Single Gimbaled Control Moment Gyroscopes. Proceedings of the 45th IEEE Conference on Decision and Control, Dec. 13-15, IEEE Xplore Press, San Diego, CA, USA, pp: 1551-1556. DOI:10.1109/CDC.2006.377310

Sands, T. and J. Kim, 2016. Experiments in control of rotational mechanics. Intl. J. Auto. Contr. Intel. Syst., 2: 9-22.

Sands, T. and J. Kim, 2017. Method and apparatus for singularity avoidance for Control Moment Gyroscope (CMG) systems without using null motion. U.S. Patent 9567112 B1.

Sands, T. and R. Mihalik, 2017. Education in nuclear deterrence and assurance. J. Def. Manag., 7: 166166. DOI: 10.4172/2167-0374.1000166.

Sands, T. and B. Agrawal, 2007. Acquisition, tracking and pointing technology development for bifocal relay mirror spacecraft. Proceedings of SPIE-The International Society for Optical Engineering. DOI: $10.1117 / 12.720694$
Sands, T. and B. Agrawal, 2009. Control moment gyroscope singularity reduction via decoupled control. Proceedings of the IEEE Southeastcon, Mar. 5-8, IEEE Xplore Press, Atlanta, GA, USA, pp: 1551-1556.

DOI: $10.1109 /$ SECON.2009.5174111

Sands, T. and B. Agrawal, 2012. Nonredundant singlegimbaled control moment gyroscopes. J. Guid. Dyn. Contr., 35: 578-587. DOI: 10.2514/1.53538

Schell, O. and J. Delury, 2013. Wealth and power: China's long march to the 21th Century. Random House, New York.

Seth, M.J.A., 2016. Concise History of Korea. 1st Edn., Rowman and Littlefield, Lanham, Maryland, ISBN10: 0742540057, pp: 257.

Setser, B., 2008. China: Creditor to the rich. China Security, 4: 17-23.

Shanker, T., 2013. U.S. Sends Two B-52 Bombers into Air Zone Claimed by China. The New York Times. http://www.nytimes.com/2013/11/27/world/asia/usflies-b-52s-into-chinas-expanded-air-defensezone.html

Office of the United States Trade Representative, 2016. Strategic Importance of TPP. https://ustr.gov/sites/default/files/TPP-StrategicImportance-of-TPP-Fact-Sheet.pdf

SIPRI, 2016. Military Expenditure. Stockholm International Peace Research Institute. https://www.sipri.org/research/armament-anddisarmament/arms-transfers-and-militaryspending/military-expenditure.

Smeresky, B., A. Rizzo and T. Sands, 2018. Kinematics in the information age. Math. Eng., Special Issue Math., 6: 148. DOI: 10.3390/math6090148

Sobel, A.C., 2006. Political Economy and Global Affairs. CQ Press, Washington D.C.

Steinberg, J. and M.E. O'Hanlon, 2015. Strategic reassurance and resolve: US-China relations in the 21 th Century. Princeton, Princeton University Press, New Jersey.

Clinton, H.R., 2014. Hard Choices. New York: Simon and Schuster.

Sudhir, T.V. and D. Low, 2014. Hard Choices. 1st Edn., Challenging the Singapore Consensus, NUS Press, ISBN-10: 9971698161, pp: 272.

Sutter, R.G., 2013. U.S.-Chinese Relations: Perilous Past, Pragmatic Present. 1st Edn., Lanham, Maryland: Rowman and Littlefield Publishers.

Central Intelligence Agency, 2016. Taiwan. In CIA World Factbook, Washington, D.C. https://www.cia.gov/library/publications/the-worldfactbook/geos/tw.html 
Thayer, C., 2015. 8 Developments in US-Vietnam relations show emerging partnership. The Diplomat. https://goo.gl/1R9a9o

The Guardian. 2016. Trump to withdraw from transpacific partnership on first day in office. https://goo.gl/jDh9JX

Tipton, E.K., 2008. Modern Japan the Nissan Institute/Routledge Japanese Study Series. Routledge, New York.

Tkacik, J.J., 2014. Maritime Taiwan and power transition in Asia. In; The US Strategic Pivot to Asia and Cross-Strait Relations: Economic and Security Dynamics, Chow, P.C.Y. (Ed.), Palgrave Macmillan, New York, ISBN-13: 978-1-34947344-1, pp: 227-261.

Tung, R.L., 2016. Opportunities and challenges ahead of China's 'new normal.' Long Range Plann., 5: 632-640.

U.S. Department of the Treasury, 2016. U.S. treasury securities held by foreign residents 1. Portfolio Holdings of U.S. and Foreign Securities, Washington

D.C. http://ticdata.treasury.gov/Publish/slt3d.txt

U.S. Census Bureau, 2016. Top Trading Partners. Foreign Trade, Washington D.C. https://www.census.gov/foreigntrade/statistics/highlights/toppartners.html

University of Texas Libraries, 2016. Map: Korea and East Sea. In Perry-Castañeda Library Map
Collection. Austin, Texas: University of Texas at Austin. http://www.lib.utexas.edu/maps/asia.html

Wang, Z., 2012. Never Forget National Humiliation: Historical Memory in Chinese Politics and Foreign Relations. In: Contemporary Asia in the World, David, C.K. and V.D. Cha., (Edn.), New York: Columbia University Press.

Washburn, D., 2012. Ambassador locke: US 'not trying to contain China.' Asia Society. http://asiasociety.org/blog/asia/ambassador-lockeus-not-trying-contain-china

Westad, O.A., 2012. Restless Empire: China and the World since 1750. 1st Edn., New York: Basic Books, ISBN-10: 0465029361, pp: 544.

White House Office of the Press Secretary, 2011. Remarks by President Obama to the Australian Parliament. Canberra. https://goo.gl/VJvEQt, 17 Nov 2011.

World Bank, 2016. Gross Domestic Product 2016. World Development Indicators Database. Washington D.C. http://data.worldbank.org/datacatalog/world-development-indicators

Yang, Y., 2009. Pentagon says Chinese vessels harassed U.S. ship. CNN. http://www.cnn.com/2009/POLITICS/03/09/us.navy .china/index.html

Zoellick, R.B., 2007. From the Shanghai communiqué to 'responsible stakeholder: Remarks at 'the China balance sheet in 2007 and Beyond'. Peterson Institute for International Economics.

\section{Appendix A Frequency Of "Pivot" Versus "Rebalance" in Written News Media}

Data Source: LexisNexis ${ }^{\circledR}$ Academic, “All News” Query.

"Pivot" vs. "Rebalance" occurrences in written news media

Note: "Rebalance" within five words of "Asia" or "Asian" resulted in skewed database hits; such a query displays predominately financial news referring to global capital or international investment rebalancing. Since the majority of publications referring to a "Rebalance to Asia" also accompanied the phrase with references to a "strategic rebalance" or "strategic rebalancing," searching for "strategic" within five words of "rebalance" or "rebalancing" produced more accurate query results.

Table 1: "All news" query

\begin{tabular}{ll}
\hline Search String & Short Name \\
\hline pivot w/5 Asia OR Asian & "Pivot" \\
strategic w/5 rebalance OR rebalancing & "Rebalance" \\
\hline
\end{tabular}

Query results

Table 2: "Pivot" vs. "rebalance" occurrences in written news media

\begin{tabular}{lllllll}
\hline Occurrences & 2010 & 2011 & 2012 & 2013 & 2014 & 2015 \\
\hline "Pivot" & 23 & 107 & 1,228 & 1,990 & 2,238 & 1,581 \\
"Rebalance" & 45 & 27 & 83 & 211 & 265 & 192 \\
\hline
\end{tabular}




\section{Appendix B Shares of Global Military Expenditures}

Source: Stockholm International Peace Research Institute (SIPRI).

The share of world military expenditure of the 15 states with the highest expenditure in 2015

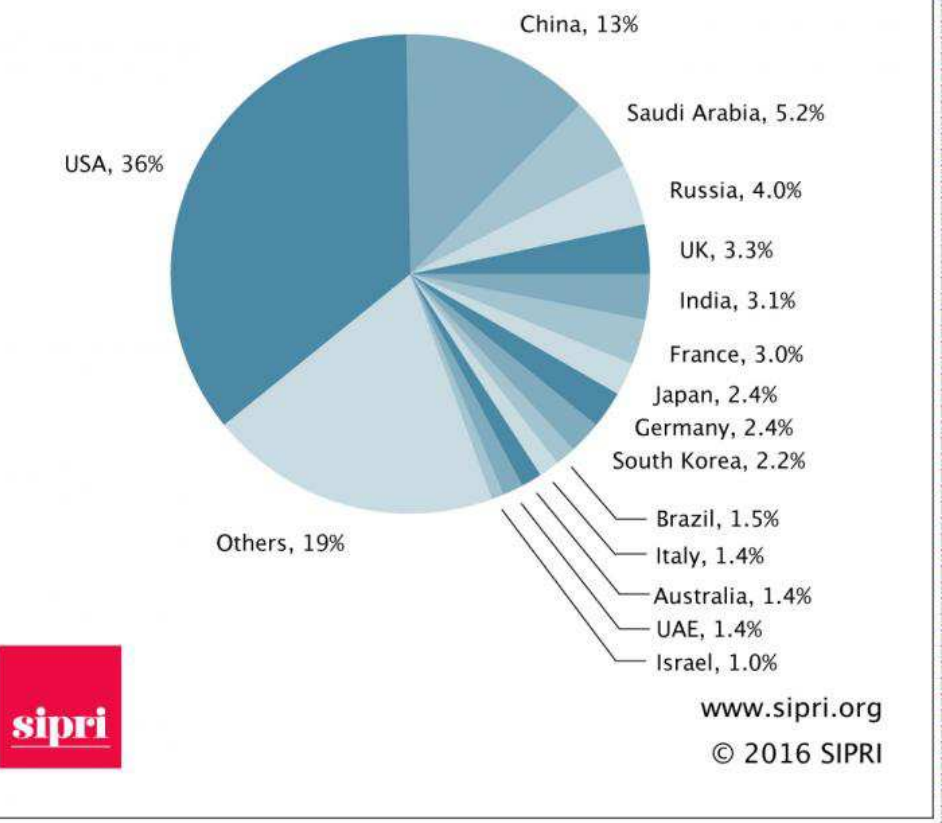

\begin{tabular}{|c|c|c|c|c|c|c|c|c|}
\hline \multicolumn{9}{|c|}{$\begin{array}{c}\text { The } 15 \text { countries with the highest } \\
\text { military expenditure in } 2015\end{array}$} \\
\hline & \multicolumn{2}{|c|}{ Rank } & \multirow[b]{2}{*}{ Country } & \multirow{2}{*}{$\begin{array}{l}\text { Spending, } \\
2015 \text { ( } \$ \text { b.) }\end{array}$} & \multirow{2}{*}{$\begin{array}{l}\text { Change, } \\
2006-15 \\
(\%)\end{array}$} & \multirow{2}{*}{$\begin{array}{l}\text { World } \\
\text { share } \\
2015(\%)\end{array}$} & $\begin{array}{l}\text { Spending } \\
\text { as a } \\
\text { share of GDP } \\
(\%)^{b}\end{array}$ & f GDP \\
\hline & 2015 & $2014^{a}$ & & & & & 2015 & 2006 \\
\hline & 1 & 1 & USA & 596 & -3.9 & 36 & 3.3 & 3.8 \\
\hline & 2 & 2 & China & [215] & 132 & {$[13]$} & {$[1.9]$} & {$[2.0]$} \\
\hline & 3 & 4 & Saudi Arabia & 87.2 & 97 & 5.2 & 13.7 & 7.8 \\
\hline & 4 & 3 & Russia & 66.4 & 91 & 4.0 & 5.4 & 3.5 \\
\hline & 5 & 6 & UK & 55.5 & -7.2 & 3.3 & 2.0 & 2.2 \\
\hline & 6 & 7 & India & 51.3 & 43 & 3.1 & 2.3 & 2.5 \\
\hline & 7 & 5 & France & 50.9 & -5.9 & 3.0 & 2.1 & 2.3 \\
\hline & 8 & 9 & Japan & 40.9 & -0.5 & 2.4 & 1.0 & 1.0 \\
\hline & 9 & 8 & Germany & 39.4 & 2.8 & 2.4 & 1.2 & 1.3 \\
\hline & 10 & 10 & South Korea & 36.4 & 37 & 2.2 & 2.6 & 2.5 \\
\hline & 11 & 11 & Brazil & 24.6 & 38 & 1.5 & 1.4 & 1.5 \\
\hline & 12 & 12 & Italy & 23.8 & -30 & 1.4 & 1.3 & 1.7 \\
\hline & 13 & 13 & Australia & 23.6 & 32 & 1.4 & 1.9 & 1.8 \\
\hline & 14 & 14 & $\mathrm{UAE}^{c}$ & {$[22.8]$} & 136 & [1.4] & {$[5.7]$} & [3.2] \\
\hline & 15 & 15 & Israel & 16.1 & 2.6 & 1.0 & 5.4 & 7.5 \\
\hline & Tota & top 15 & & 1350 & & 81 & & \\
\hline & Worl & total & & 1676 & 19 & 100 & 2.3 & 2.3 \\
\hline & $\begin{array}{l}{[]=S} \\
\text { Wezen } \\
\text { Fact S }\end{array}$ & $\begin{array}{l}\text { PRI estim } \\
\text { an, P. an } \\
\text { eet, Stoc }\end{array}$ & $\begin{array}{l}\text { nate. For notes } \\
\text { nd Wezeman, S } \\
\text { ckholm, Apr. } 2\end{array}$ & $\begin{array}{l}\text { and sources } \\
\text { 'Trends in } \\
\text { 16. }\end{array}$ & $\begin{array}{l}\text { see Perlo- } \\
\text { military ex }\end{array}$ & $\begin{array}{l}\text {-Freeman, } \\
\text { kpenditure }\end{array}$ & $\begin{array}{l}\text { S., Fleur } \\
2015\end{array}$ & $\begin{array}{l}\text { rant, A., } \\
\text { SIPRI }\end{array}$ \\
\hline \multirow{2}{*}{ sipri } & & & & & & & & www.sipri.org \\
\hline & & & & & & & & (C) 2016 SIPRI \\
\hline
\end{tabular}




\section{Appendix C GDP of Selected Nations (PPP)}

Data Source: World Bank; Taiwan Data Source: Central Intelligence Agency, "Taiwan."

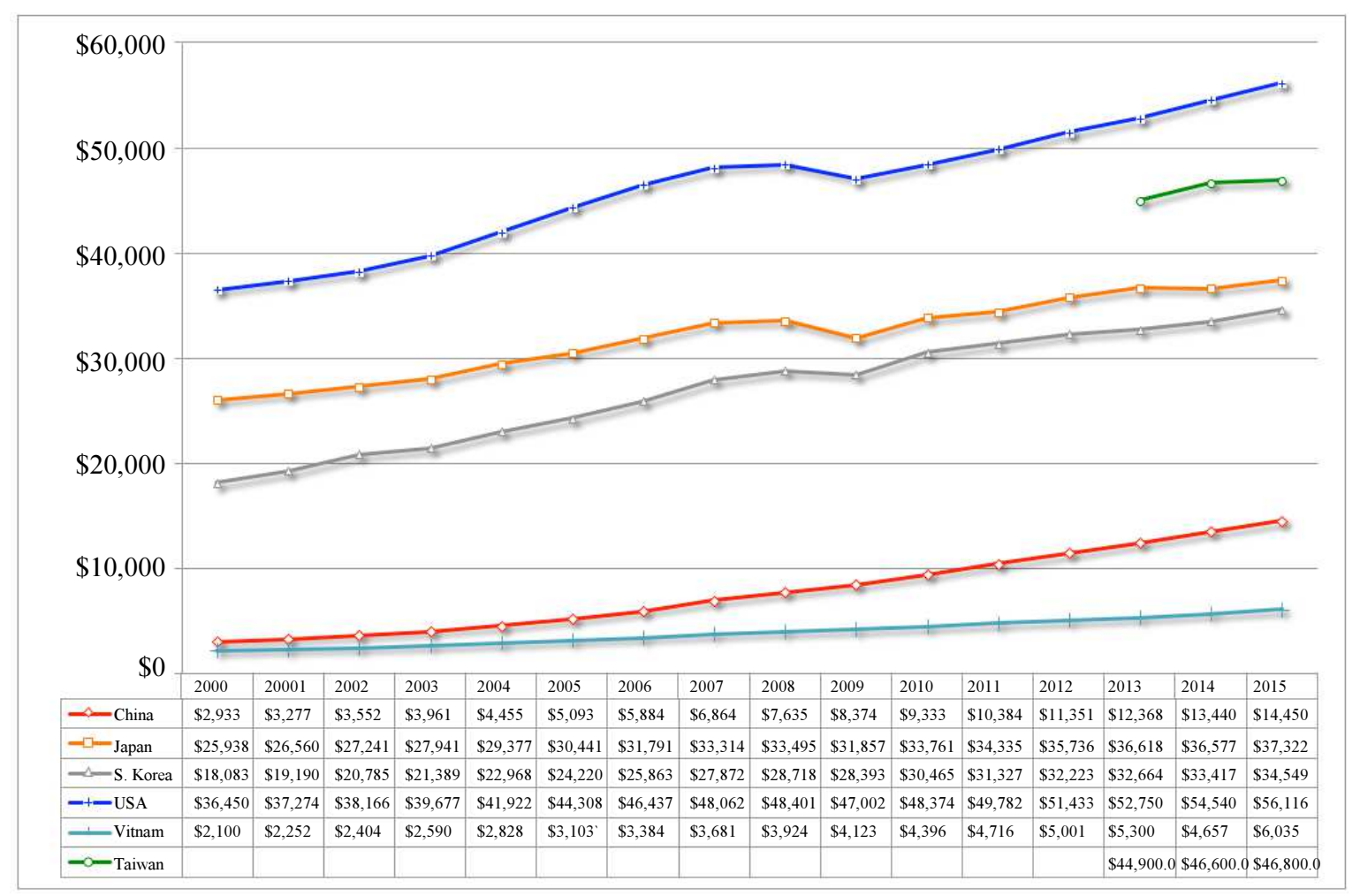

\section{Appendix D U.S. Military Personnel Distribution}

Table 3: DoD personnel distribution data source: Defense manpower data center

\begin{tabular}{|c|c|c|c|c|}
\hline & 2012 & 2013 & 2014 & 2015 \\
\hline DoD Total Mil End Strength & $1,393,948$ & $1,372,336$ & $1,310,842$ & $1,305,292$ \\
\hline DoD Total Europe & 78,528 & 69,065 & 68,147 & 65,356 \\
\hline DoD Total East Asia and Pacific & 53,495 & 51,259 & 51,363 & 79,794 \\
\hline DoD Undistributed & 45,701 & 37,352 & 36,345 & 4,496 \\
\hline Army Total Force & 550,484 & 530,382 & 489,383 & 491,911 \\
\hline Army Europe & 40,804 & 31,830 & 30,285 & 28,580 \\
\hline Army East Asia and Pacific & 2,611 & 2,564 & 2,474 & 23,047 \\
\hline Army Undistributed & 20,472 & 22,677 & 21,675 & 848 \\
\hline Navy Total Force & 317,002 & 318,845 & 320,169 & 321,315 \\
\hline Navy Europe & 6,043 & 5,957 & 6,644 & 6,801 \\
\hline Navy East Asia and Pacific & 19,350 & 20,248 & 20,400 & 20,312 \\
\hline Navy Undistributed & 571 & 1,145 & 305 & 3 \\
\hline Marine Corps Total Force & 197,266 & 194,227 & 185,697 & 184,688 \\
\hline Marine Corp Europe & 919 & 884 & 1,020 & 1,055 \\
\hline Marine Corps East Asia and Pacific & 18,809 & 15,717 & 15,944 & 16,290 \\
\hline Marine Corp Undistributed & 16,506 & 4,547 & 5,137 & 2,492 \\
\hline Air Force Total Force & 329,196 & 328,882 & 315,593 & 307,378 \\
\hline AF Europe & 30,762 & 30,394 & 30,198 & 28,920 \\
\hline AF East Asia and Pacific & 12,725 & 12,730 & 12,545 & 20,145 \\
\hline AF Undistributed & 8,152 & 8,983 & 9,228 & 1,153 \\
\hline DoD Civ End Strength & 744,847 & 770,252 & 744,151 & 733,020 \\
\hline DoD Civ Europe & 26,055 & 24,110 & 25,661 & 25,577 \\
\hline DoD Civ East Asia and Pacific & 9,690 & 9,466 & 9,045 & 19,879 \\
\hline DoD Civ Undistributed & 11,896 & 11,475 & 11,285 & 554 \\
\hline
\end{tabular}

Infographic source: Center for International and Strategic Studies 


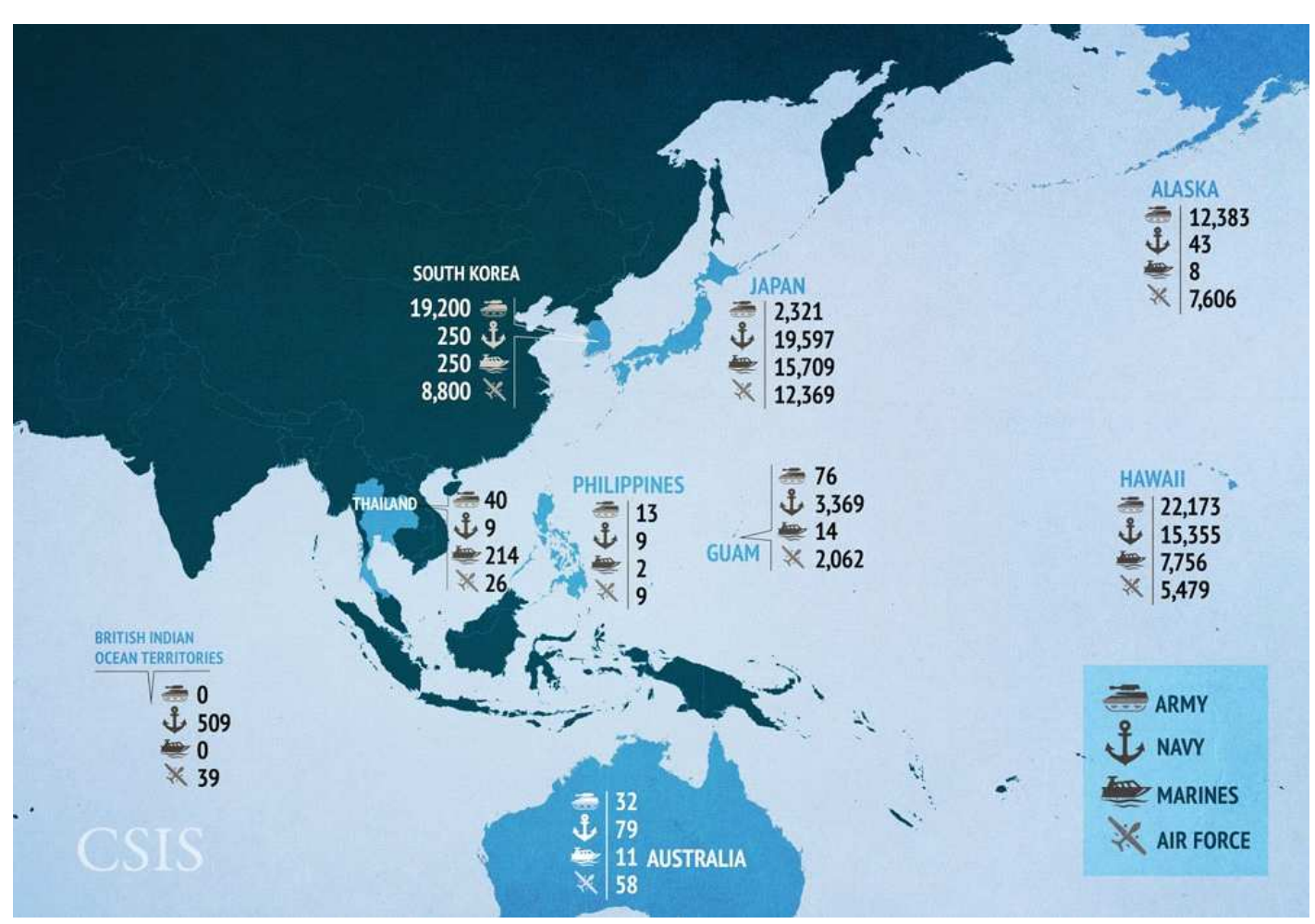

\section{Appendix D U.S. Military Personnel Distribution}

Presidential Travel

\begin{tabular}{llllllllll}
\hline President & Europe & Asia & Central Asia & Africa & South America & Middle East & Oceana & Caribbean & North America \\
\hline Bush & 54 & 22 & 10 & 10 & 18 & 20 & 2 & 0 & 4 \\
Obama & 38 & 25 & 3 & 8 & 13 & 14 & 2 & 3 & 3 \\
\hline
\end{tabular}

\begin{tabular}{ll}
\hline President & Total international trips \\
\hline Bush & 140 \\
Obama & 109 \\
\hline
\end{tabular}

\begin{tabular}{lll}
\hline & & \\
\hline Region & Bush (trips) & Obama(trips) \\
\hline Europe & 54 & 38 \\
Asia & 22 & 25 \\
Central Asia & 10 & 3 \\
Africa & 10 & 8 \\
South America & 18 & 13 \\
Middle East & 20 & 14 \\
Oceana & 2 & 2 \\
Caribbean & 0 & 3 \\
North America & 4 & 3 \\
\hline
\end{tabular}

\begin{tabular}{|c|c|c|c|c|c|c|c|c|c|c|c|c|c|c|c|c|c|c|c|}
\hline President & Bangladesh & Brunei & Burma Cambodia & China & India & Indonesia & Japan & Laos & Malaysia & Maldives & Mongolia & Nepal & Pakistan & Philippines & Singapore & Sri Lanka & South Korea & Thailand & Vietnam \\
\hline $\begin{array}{l}\text { Bush } \\
\text { But }\end{array}$ & 0 & $\begin{array}{l}0 \\
0\end{array}$ & $\begin{array}{ll}0 & 0 \\
\end{array}$ & 4 & 1 & 2 & 4 & $\begin{array}{l}0 \\
0 \\
0\end{array}$ & 0 & $\begin{array}{ll}0 \\
0\end{array}$ & 1 & 0 & 1 & 1 & 2 & 0 & 3 & 2 & 1 \\
\hline
\end{tabular}

Travel by Secretaries of State

\begin{tabular}{llllllrrrl} 
& & & Central & & South & Middle & & North \\
Secretary & Europe & Asia & Asia & Africa & America & East & Oceana & Caribbean & America \\
\hline Powell & 61 & 38 & 13 & 21 & 20 & 51 & 0 & 4 & 5 \\
Rice & 76 & 33 & 20 & 14 & 21 & 100 & 5 & 2 & 3 \\
Clinton & 69 & 33 & 18 & 18 & 31 & 27 & 34 & 4 & 5 \\
Kerry & 152 & 41 & 15 & 17 & 13 & 91 & 3 & 4 & 5 \\
\hline
\end{tabular}


Lucas Bittick and Timothy Sands / Journal of Social Sciences 2019, Volume 15: 92.125 DOI: 10.3844/jssp.2019.92.125

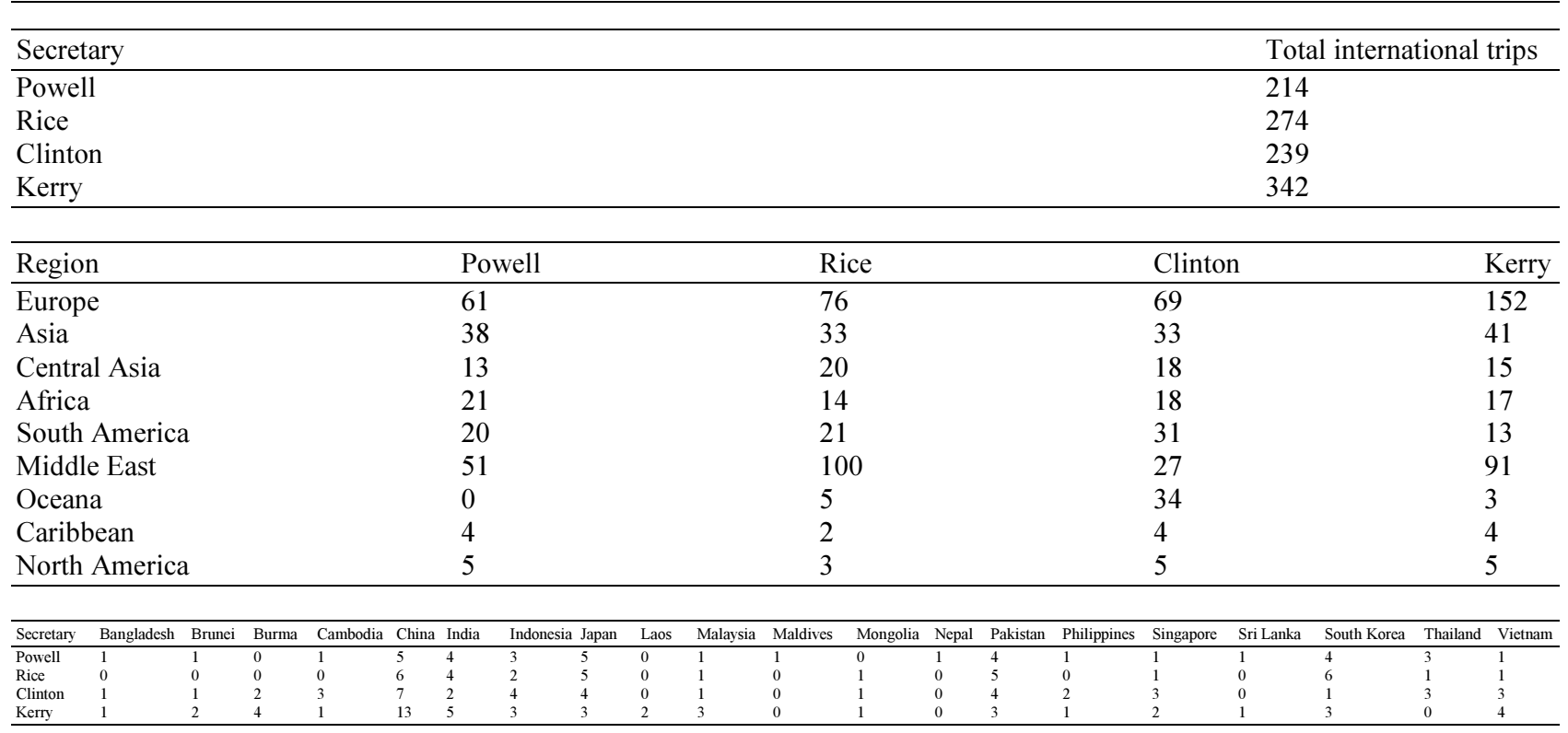

